\title{
Notes florístiques de les conques altes dels rius Segre i Llobregat (II)
}

\author{
Pere Aymerich \\ C/ Barcelona, 29. 08600 Berga \\ pere_aymerich@yahoo.es
}

Manuscrit rebut el desembre de 2013

\section{Resum}

Aportem dades florístiques d'uns 80 tàxons a les conques superiors del Segre i el Llobregat, una zona de la meitat est dels Pirineus ecològicament heterogènia, amb altituds que van des de 400 fins a 2900 m. Entre les plantes autòctones, Persicaria minor (Huds.) Opiz és novetat per a la flora de Catalunya, mentre que Daphne alpina L., Epipogium aphyllum Sw. i Equisetum fluviatile L. són espècies molt rares i amenaçades. Destaquem també la primera citació de Mercurialis huetii Hanry en una vall dels Pirineus i noves localitats de Sisymbrium macroloma Pomel, planta molt escassa a Catalunya. Una tercera part dels tàxons citats són al·lòctons, dels quals són novetat per a la flora de Catalunya Acer saccharinum L., Aubrieta columnae Guss., Bunias orientalis L., Muscari armeniacum Leichtlin ex Baker, Rhus typhina L. i Solanum physalifolium Rusby. Confirmem també la presència al territori de Galega officinalis L. i Ribes rubrum L., les citacions prèvies de les quals eren antigues i sovint dubtoses.

Paraules clau: flora; corologia; plantes al-lòctones; Pirineus; Catalunya; NE península Ibèrica.

\section{Abstract. Floristic data of the upper Segre and Llobregat basins (II)}

We report floristic data on some 80 taxa in the upper Segre and Llobregat basins, a very ecologically diverse area of the Eastern Pyrenees with altitudes ranging from 400 to 2900 $\mathrm{m}$. Among the native plants, Persicaria minor (Huds.) Opiz is new to the flora of Catalonia, while Daphne alpina L., Epipogium aphyllum Sw. and Equisetum fluviatile L. are very rare and endangered species. We also report the first record of Mercurialis huetii Hanry in a Pyrenean valley and new sites of Sisymbrium macroloma Pomel, a very scarce plant in Catalonia. A third of the reported species are alien plants, of which the Catalan flora Acer saccharinum L., Aubrieta columnae Guss., Bunias orientalis L., Muscari armeniacum Leichtlin ex Baker, Rhus typhina L., and Solanum physalifolium Rusby are new. Furthermore, we confirm the presence of Galega officinalis L. and Ribes rubrum L. in the territory, for which prior citations were ancient and often dubious.

Keywords: flora; chorology; alien plants; Pyrenees; Catalonia; north-eastern Iberian Peninsula. 


\section{Introducció}

L'àmplia zona de muntanyes i valls que abasten les conques altes dels rius Segre i Llobregat presenta una diversitat ambiental notable, que es tradueix en una flora diversa - el nombre de tàxons de flora vascular supera força els 2000 — i singular —és l'àrea amb més densitat d'endemismes de Catalunya (Sáez et al., 2010) i també hi ha una quantitat considerable de plantes rares o amenaçades a escala regional- Aquesta flora és força ben coneguda, gràcies a uns quants catàlegs locals (Vives, 1964; Rosell, 1978; Soriano, 1992; Vigo et al., 2003; Sáez et al., 2004; Devis, 2006) i, sobretot, a nombroses aportacions parcials fetes des del segle XIX, en forma d'articles o de dades integrades en obres de caràcter més general. Tot i això, encara són habituals les troballes de nous tàxons o les ampliacions importants de la informació sobre altres ja coneguts, en uns casos com a conseqüència de l'heterogeneïtat del territori i les dificultats que comporta explorar-lo de manera detallada, i en d'altres per la incorporació recent de plantes al-lòctones.

$\mathrm{Amb}$ aquesta nota donem a conèixer dades que hem obtingut en els darrers anys, i que contribueixen a millorar el coneixement de la flora de la zona considerada. Es tracta d'informacions heterogènies, referides en general a novetats florístiques (a escala regional o catalana), a tàxons que són rars a escala regional o local i a ampliacions destacables de l'àrea catalana coneguda d'algunes plantes. Amb aquest treball donem continuïtat a les aportacions periòdiques a la flora regional que hem estat realitzant des de fa una quinzena d'anys, sobretot en un article homònim (Aymerich, 2003) i en altres publicacions centrades en algunes parts d'aquest mateix àmbit geogràfic (Aymerich, 1998; Vigo et al., 2003; Aymerich et al., 2008).

\section{Material i mètodes}

L'àmbit geogràfic del qual provenen les dades florístiques que s'exposen és una àrea gran i heterogènia del nord de Catalunya, que abasta les conques altes dels rius Segre (amb límit sud al congost d'Organyà) i Llobregat (amb límit sud al baix Berguedà). L'extensió del territori considerat és d'uns $2000 \mathrm{~km}^{2}$, la major part dels quals són ocupats per muntanyes (sectors axials dels Pirineus i serres prepirinenques). Les altituds van des de $400 \mathrm{~m}$ fins a $2900 \mathrm{~m}$ i hi estan representats una gran diversitat d'hàbitats i bioclimes, des dels mediterranis de tendència continental fins als de l'estatge alpí. Administrativament, aquest territori és inclòs en quatre comarques: la Baixa Cerdanya de forma completa, i parcialment l'Alt Urgell, el Berguedà i el Solsonès. A la conca del Segre, llevat d'alguna excepció puntual, totes les dades es refereixen a la part inclosa dins la Catalunya autònoma, és a dir, que no s'han considerat les parts d'aquesta conca dins els territoris administratius d'Andorra i de França (Alta Cerdanya). Excepcionalment hem afegit alguna dada de l'alt Ripollès occidental, de localitats molt pròximes a les conques del Segre i del Llobregat.

Les dades florístiques es presenten separades en dos grups, primer un de tàxons autòctons de Catalunya i després un de tàxons al-lòctons; dins cada grup, els 
tàxons es presenten per ordre alfabètic. La referència nomenclatural habitual és Flora iberica (Castroviejo et al., 1986-2013), però en alguns casos hem recorregut a noms que considerem més actualitzats o més adequats. La informació de cada espècie consisteix en una citació florística amb el format habitual i després un comentari més o menys extens que contextualitza l'interès relatiu de la citació. En cada citació s'indica, en aquest ordre: comarca, municipi, indret, quadrat UTM 1 x 1 (sempre dins el fus 31T i amb sistema de referència ETRS89), altitud, hàbitat i data d'observació. Els topònims de referència utilitzats són els de la base cartogràfica de l'Institut Cartogràfic de Catalunya (http://www.icc.cat), amb el nivell de detall considerat més adequat en cada cas. De les localitats marcades amb asterisc (*) n'hem dipositat plecs testimoni a l'Herbari BCN. Els comentaris que segueixen la citació són molt diversos, segons els casos, però es refereixen sobretot a la singularitat de les poblacions locals en relació amb una distribució més general del tàxon, al seu origen (espècies introduïdes) o a la mida poblacional i factors de risc (plantes protegides o molt rares). Les referències principals utilitzades per a contextualitzar les citacions dins l'àrea general de cada tàxon a Catalunya han estat el Banc de Dades de Biodiversitat de Catalunya (http://biodiver. bio.ub.es/biocat/homepage.html, citat com a BDBC), els diversos volums de l'atlas florístic ORCA i les síntesis florístiques modernes (Bolòs \& Vigo, 1984-2001; Bolòs et al., 2005). Les consultes a BDBC han estat fetes entre l'agost i el novembre de 2013, i també corresponen a aquest mateix període les consultes més puntuals a altres bases de dades que citem al text.

\section{Resultats: dades florístiques}

\section{Tàxons autòctons}

\section{Aegilops triuncialis L. subsp. triuncialis}

Alt Urgell: el Pont de Bar, solells sobre el poble, CG8592, 890 m, pradells terofítics en marges de camí i camps abandonats, 7-VII-2013.

Gramínia de distribució mediterrània que no sabem que hagués estat citada fins ara del sector axial dels Pirineus, tot i que sí de les serres prepirinenques (Bolòs \& Vigo, 2001; Villar et al., 2001; BDBC). Ateny aquests solells molt insolats de l'alta vall del Segre, juntament amb altres plantes termòfiles, algunes de les quals citem en aquesta mateixa nota.

\section{Androsace halleri L.}

Cerdanya: Lles de Cerdanya, bac de la Muga, damunt l'estany petit de la Muga, CH9002, $2700 \mathrm{~m}$, sòls pedregosos silicis, amb cobertura vegetal molt feble, 30-VII-2013.

Segona localitat d'aquesta espècie al sector Tosa Plana-Puigpedrós, on es va detectar fa poc (Aymerich, 2013c) uns $3 \mathrm{~km}$ més cap a l'oest. Fins llavors, a la serralada pirinenca, la distribució coneguda d'A. halleri es limitava als Pirineus orientals estrictes — al sud de la fossa de la Cerdanya- i, molt puntualment, al Carlit. Al sector Tosa Plana-Puigpedrós, en canvi, només era coneguda A. laggeri 
A. Huet, que no hem vist a les àrees visitades però ha estat citada de diverses localitats andorranes (Galicia et al., 2002). En aquest sector A. halleri sembla una espècie realment rara, ja que només l'hem vista en dos llocs malgrat haver visitat molts hàbitats potencials, i a més les poblacions locals són poc nombroses (unes quantes desenes o pocs centenars d'individus) i ocupen superfícies de pocs $\mathrm{m}^{2}$.

Androsace vitaliana (L.) Lapeyr. subsp. cinerea (Sünd.) Kress [Vitaliana primuliflora Bertol. subsp. cinerea (Sünderm.) I.K. Ferguson]

Alt Urgell: les Valls de Valira, Bescaran, serra Airosa, diversos punts de la carena i del vessant sud-oest, CH8300-8400, 2620-2660 m, sòls pedregosos sobre esquistos, 2-VIII-2013; les Valls de Valira, Bescaran, cap al coll de la Barra, CG8598, 2460 m, sòls pedregosos sobre esquistos, 16-VIII-2013; les Valls de Valira, Bescaran, entre el coll de la Barra i el turó Punçó, CG8598, 2450 m, sòls pedregosos sobre esquistos, 16-VIII-2013.

Tot i que A. vitaliana s.l. ja havia estat indicada de diverses localitats d'aquest sector pirinenc, considerem convenient assenyalar que els diversos nuclis que hem observat a Bescaran són referibles a la subsp. cinerea, mentre que les citacions prèvies corresponien a la subsp. vitaliana (sub Vitaliana primuliflora subsp. canescens O. Schwarz) o bé no precisaven la subespècie (Bolòs et al., 2001; $\mathrm{BDBC}$ ). Confirmem l'existència de la subsp. cinerea als Pirineus centrals, on és assenyalada explícitament com de «presència no segura» per Kress (1997). A Catalunya, Bolòs \& Vigo (1996) no citen la subsp. cinerea d'aquesta part de la serralada, mentre que al BDBC hi és indicada en un sol quadrat a la Ribagorça. El Sistema d'Informació de la Biodiversitat d'Andorra (www.siba.ad) també la cita d'Andorra, en un sol quadrat d'1 x 1 km, adjacent als que aquí aportem. Aquesta subespècie és ben coneguda dels Pirineus orientals, en l'eix serra del Cadí-Puigmal (Vigo, 1983; Bolòs et al., 2001; Vigo et al., 2003), i la seva presència al sector Tosa Plana-Puigpedrós resulta coherent amb la d'altres tàxons bàsicament pirenaico-orientals, com Androsace halleri i Xatardia scabra, també comentats en aquesta nota, o altres com Jacobaea leucophylla (DC.) Pelser, Endressia pyrenaica (J. Gay ex DC.) J. Gay o Ranunculus angustifolius DC.

\section{Arctium lappa $\mathrm{L}$.}

Alt Urgell: Alàs i Cerc-la Seu d'Urgell, ribera del Segre, CG7490-7590-7690, 690-700 m, exemplars escampats en herbassars nitròfils al bosc de ribera, 7-VIII2013; Ribera d'Urgellet, el Pla de Sant Tirs, ribera del Segre a Culinoves, CG6585, 600 m, herbassars nitròfils al bosc de ribera, 7-VIII-2013. CERDANYA: Bellver de Cerdanya, basses de Gallissà, al marge esquerre del Segre, CG9791, 995 m, herbassars nitròfils al bosc de ribera, 9-IX-2013; Bellver de Cerdanya, riberal del Segre cap al Prat de Codina, CG9891, 1000 m, marges de prats de dall, 9-IX2013; Bolvir, al nord-est de Talltorta, DG0995, 1095 m, herbassars vora una sèquia, 2-IX-2013; Bolvir, cap a l'aiguabarreig dels rius Segre i Querol, DG0994, 1080 m, marges de prats de dall, 2-IX-2013; Ger-Isòvol, Prades de Segre, DG0593-0594, $1050 \mathrm{~m}$, clarianes i marges de camins al bosc de ribera, 22-VIII2013; Lles de Cerdanya, ribera del Segre entre Martinet i els Banys de Músser, 
CG9190, 940-950 m, bosc de ribera, 10-X-2013; Prullans, la Riberola, al marge dret del Segre, CG9691, 990 m, clarianes del bosc de ribera, 9-IX-2013.

Aquesta espècie és rara als Pirineus centrals, i a l'alt Segre només en coneixíem una citació pròpia just a la frontera hispano-andorrana (Font \& Vigo, 2008) i una altra de la Guàrdia d'Ares, al quadrat CG58 (Romo, 1988). Les dades que presentem mostren que és freqüent a la ribera del Segre, tot i que força local i escassa. A les localitats de la Cerdanya també hi hem vist individus amb alguns caràcters intermedis entre A. lappa i A. minus, que suposem que correspondrien a l'híbrid Arctium x nothum (Ruhmer) J. Weiss.

\section{Artemisia eriantha Ten.}

Cerdanya: *Lles de Cerdanya, Vallcivera, vessant nord del pic de la Muga, CH9103, $2800 \mathrm{~m}$, fissures de roques silícies, en exposició nord, 31-VII-2013.

Espècie molt rara als Pirineus catalans i que, segons la informació disponible, no havia estat citada fins ara de la Cerdanya (Bolòs \& Vigo, 1996; Font \& Vigo, 2008; BDBC). Al BDBC apareix indicada del mateix quadrat UTM CH90, però aquesta citació correspon a territori andorrà, més concretament al sector del pic Negre d'Envalira, que és on aquest tàxon té el límit oriental conegut als Pirineus.

\section{Asphodelus cerasiferus J. Gay}

Cerdanya: Urús, costat dret del torrent de la Fou, DG0588, 1350 m, relleixos i base de cingles calcaris, 10-VI-2013.

La informació sobre les espècies d'Asphodelus existents en aquest sector pirinenc és insuficient, ja que han estat habituals les confusions d'A. macrocarpus amb A. albus i amb A. cerasiferus. Com s'indica en treballs previs (Aymerich, 2003; Vigo et al., 2003), les poblacions dels estatges montà i subalpí corresponen en general a A. macrocarpus, mentre que A. cerasiferus està limitat a cingles càlids de baixa altitud, i fins ara havia estat documentat només dels Prepirineus del Berguedà; a l'alt Ripollès, ambdues espècies segueixen un patró similar (Aymerich et al., 2012). Amb aquesta nota confirmem la presència d'A. cerasiferus a la Cerdanya, i suposem que deu estar present també en altres cingles fortament insolats de l'alta vall del Segre.

\section{Asplenium scolopendrium L.}

BERGUedè: Avià, riba esquerra del Llobregat entre la Plana i la Colònia Rosal, DG0657, 470 m, parets d'un canal, X-2013.

Aquesta falguera és molt rara a les serres prepirinenques de la zona considerada, on tot just se'n coneixen 6 o 7 poblacions (Aymerich, 2003; Vigo et al., 2003; Aymerich et al., 2008). La nova localitat que aportem és singular perquè ja se situa en plena depressió central i perquè tots els individus - una quinzenacreixen en un hàbitat antròpic, les parets d'un canal paral·lel al Llobregat.

\section{Astragalus stella $\mathrm{L}$.}

Alt Urgell: el Pont de Bar, solells sobre el poble, CG8592, $890 \mathrm{~m}$, pradells terofítics en marges de camí i camps abandonats, 7-VII-2013. 
Aquest teròfit mediterrani no havia estat indicat de l'alta vall del Segre. Les localitats conegudes més pròximes en aquesta vall se situen a la rodalia d'Oliana, segons el BDBC.

Berberis vulgaris L. subsp. seroi O. Bolòs \& Vigo

Cerdanya: Bolvir, Talltorta, vora el pont del Querol, DG0995, 1090 m, mur de pedra seca al marge d'un prat de dall, 28-X-2013.

Tàxon molt rar a Catalunya, del qual no coneixem cap dada publicada de la Cerdanya (Sáez et al., 2010; BDBC). El nucli trobat a Talltorta presenta només tres individus molt junts, i segueix el patró habitual de les poblacions del tàxon al nord de Catalunya (proximitat a cases, hàbitat més o menys antròpic, feblesa demogràfica). Com ja havíem comentat (Aymerich, 2013a), aquestes característiques fan que considerem molt probable que es tracti d'una planta localment introduïda a consequiència d'un antic cultiu a petita escala, que hauria tingut com a finalitat un ús tintori o potser medicinal.

\section{Cardamine flexuosa With.}

Cerdanya: Bellver de Cerdanya, Santa Eugènia, cap a Cal Pubill, CG9691, 985 m, 21-V-2011; Bolvir, riberal del Segre cap als Clots de Bolvir, DG0895, vores de sèquies i herbassars higròfils dins les vernedes, V i X-2013; Ger, riba esquerra del riu Segre, DG0694, 1055 m, verneda, 13-VI-2013; Isòvol, Prades de Segre, DG0594, 1050 m, verneda, 24-IV-2013; Prats i Sansor, entre el congost d'Isòvol i el molí de Prats, DG0291, 1030 m, verneda, 24-IV-2013; Prullans, la Riberola, CG9591, $980 \mathrm{~m}$, verneda, 21-V-2011.

Espècie rara a les valls dels Pirineus centrals catalans, que a l'alt Segre només sabem que hagi estat citada d'un parell de localitats (Bolòs et al., 1997; Vigo et al., 2003; BDBC). Afegim noves poblacions de la Cerdanya, totes en vernedes eutròfiques i temporalment inundades del riu Segre, hàbitat en el qual $C$. flexuosa resulta puntualment abundant i pot ser inadvertida a causa de la floració força primerenca.

\section{Cerastium gracile Dufour}

BerguedÀ: Gironella, sobre la urbanització Cal Ramons, DG0853, 510 m, codines en afloraments de gresos carbonatats, 9-V-2013.

Localitat que amplia cap a l'est, de manera notable, l'àrea d'aquesta espècie força estesa a les zones seques de la Catalunya occidental i meridional (BDBC). La citació més pròxima coneguda se situa al límit del Solsonès i la Segarra.

\section{Daphne alpina L.}

Cerdanya: Riu de Cerdanya, al sud de Canals, DG0386, 1455 m, prat pedregós, 23-V-2014.

Hi hem observat un sol individu, reproductor i de mida mitjana, al costat d'una pista forestal. Suposem que als cingles propers deu existir alguna població més nombrosa, però la prospecció feta fins ara no ens ha permès trobar cap altre individu. Aquesta localitat se situa uns 6,5 km més cap a l'est de l'única fins ara documentada a Catalunya d'aquesta espècie, a la vall de Pi (Gruber, 1977; Sáez et al., 2010). 


\section{Epipogium aphyllum $\mathrm{Sw}$.}

BerguedÀ: Saldes, baga de Gresolet, CG9379, 1460 m, fageda, 27-VII-2013. Fig. 1.

A la dècada de 1980, M.T. Sebastià — qui aleshores feia a la zona un treball de recerca (Sebastià, 1983) — va comentar que havia vist un individu d'aquesta rara orquídia al bosc de Gresolet, sense aportar-ne plec testimoni ni fotografies, motiu pel qual aquesta dada es va considerar poc fiable o probablement errònia, no es va tenir en compte en síntesis florístiques catalanes ni regionals (Bolòs \& Vigo, 2001; Vigo et al., 2003) i, a la pràctica, es va quedar en un simple rumor. Tot i això, la informació sí que va ser recollida a Sáez et al. (2010) com a possible observació de l'espècie, ja que hi havia hàbitats potencials i semblava una planta difícil de confondre. Recentment hem pogut confirmar que E. aphyllum existeix realment a Gresolet, bé que només n'hem pogut observar un individu, localitzat en una taca de fageda amb arbres de dimensions grans i estructura de bosc madur. Les condicions meteorològiques de 2013, amb una primavera molt plujosa i fresca, segurament han afavorit la floració d'aquesta poc predictible orquídia i la seva detecció. Aquesta localitat s'afegeix a les tres fins ara conegudes d'aquesta espècie a Catalunya autònoma, dues de les quals al Pallars Sobirà (vall de la Bonaigua) i l'altra al Montseny (Pontacq \& Nuet, 1999; Benito Ayuso et al., 2003; Sáez et al., 2010; Vila, 2010), bé que les poblacions més pròximes se situen a la Catalunya Nord, on se n'han citat fins a onze a la vall alta del riu Tet (Lewin, 1998; Hourcq, 2007).

\section{Equisetum fluviatile L.}

Cerdanya: *Bolvir, a l'oest de la Molina de Bolvir, DG0795, 1065 m, depressió inundada al riberal del Segre, 16-X-2013.

Espècie que a la Catalunya autònoma només havia estat citada de l'Aran (Ballesteros, 1989; Sáez, 1997; Sáez et al., 2010), tot i que les poblacions més pròximes a la de Bolvir se situen a l'Alta Cerdanya (vall de la Bullosa) i al Capcir (Amigó, 2001; SCOP Sagne, 2007); a una distància una mica més gran també es coneix d'una localitat andorrana, a la vall d'Incles (Lazare et al., 2009; www.siba.ad). Citacions antigues d'aquesta espècie als «prados húmedos de Cerdaña» (Vayreda, 1882) han estat considerades tradicionalment errònies — ja des de Cadevall (1937) — i molt probablement ho eren, ja que referències del mateix autor al litoral del nordest de Catalunya s'ha constatat que corresponien a confusions amb E. ramosissimum. A la localitat de Bolvir hem observat una població relativament nombrosa (uns quants centenars de tiges), que viu en una depressió entollada amb aigua que hi circula molt lentament, on aquest equiset creix força barrejat amb Typha latifolia. Sembla que aquesta depressió es va reblint progressivament amb sediments, procés que pot causar a mitjà termini una regressió d'E. fluviatile, ja que el rebliment afavoreix el domini de T. latifolia, espècie que l'any 2013 feia un poblament quasi monoespecífic que ocupava més de la meitat de la superfície.

\section{Euphorbia platyphyllos L.}

Berguedà: Avià, riba del Llobregat a la Plana, DG0656, 470 m, entre un marge de camí i una bardissa, XI-2013. 


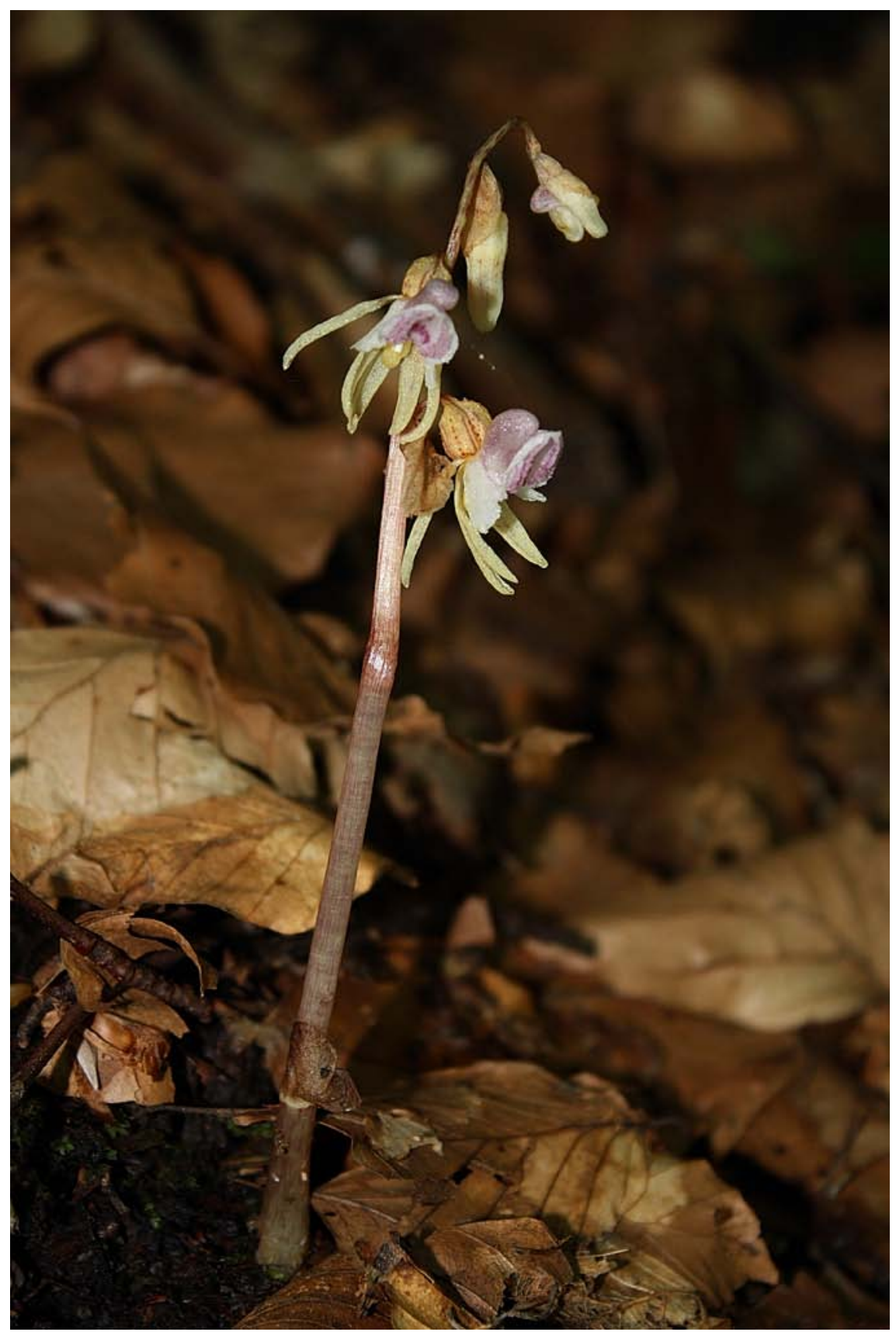

Figura 1. L'únic individu d'Epipogium aphyllum observat a Gresolet l'estiu de 2013. 
Dins l'àmbit d'aquest article només coneixem una citació d'aquesta planta, prop de la Seu d'Urgell, i no hauria estat citada en tota la conca alta i mitjana del riu Llobregat (Bolòs et al., 1999; BDBC). Les indicacions més pròximes a la d'Avià se situen a la plana de Vic i al Moianès (BDBC). Hi vam observar només dos individus, i no es pot excloure que es tracti d'una aparició accidental.

\section{Euonymus europaeus L.}

Cerdanya: Bolvir, cap als Platers, DG0895, 1100 m, bardissa, 28-X-2013; Lles de Cerdanya, ribera del Segre entre Martinet i els Banys de Músser, CG9190, 940-950 m, bardissa, 10-X-2013.

Aquest arbret no havia estat citat de la conca superior del Segre (BDBC) i en general és rar al vessant sud dels Pirineus centrals. Les localitats més pròximes se situen a l'alt Llobregat (Vigo et al., 2003), mentre que a la conca del Segre reapareix en zones prepirinenques del congost d'Organyà (Gamisans \& Gruber, 1988) i de la vall de la Vansa (Aymerich et al., 2008).

Fraxinus angustifolia (Vahl.) subsp. oxycarpa (M. Bieb ex Willd.) Franco \& Rocha Afonso

Alt Urgell: Montferrer i Castellbò-Ribera d'Urgellet, ribera del riu Segre entre les Bordes d'Arfa i Arfa, CG6987-7088-7189, 640-660 m, bosc de ribera, 13-VII-2013.

A Catalunya aquest tàxon ha estat indicat sobretot de les comarques marítimes del nord-est i del tram final del riu Ebre (BDBC). A la conca del Segre només en coneixem una citació antiga de la plana de Lleida, concretament d'Alcoletge (Braun-Blanquet \& Bolòs, 1957). A la localitat de l'Alt Urgell que indiquem hem vist una vintena d'individus escampats al bosc de ribera, convivint amb F. excelsior, aquest molt abundant. Considerem probable que es tracti d'un tàxon localment introduït, ja que aquest tram del Segre té un bosc de ribera força alterat i va ser objecte d'obres hidràuliques i revegetacions els anys 1980 i 1990. En tot cas, amb independència de l'origen, hem observat que es reprodueix amb èxit.

Glaucium corniculatum (L.) Curtis

Alt Urgell: el Pont de Bar, solell sobre el poble, CG8592, 890 m, talús en un camp abandonat, 7-VII-2013.

Espècie que gairebé no ha estat citada a l'àmbit pirinenc (BDBC), on és probable que només faci poblacions esporàdiques o accidentals. La citació més pròxima és de la Parròquia d'Hortó, al sud de la Seu d'Urgell (Carreras, 1993), i més a l'est també ha estat indicada puntualment de l'alt Llobregat (Vigo et al., 2003). Al Pont de Bar hi vam observar un nucli petit, de només una desena d'individus.

Gnaphalium norvegicum Gunnerus

Cerdanya: *Lles de Cerdanya, vessant meridional del pic del Coll de la Barra, CG8599, 2400-2500 m, vessants de sòl pedregós i inestable, sobre granits, 16VIII-2013.

Al sector Tosa Plana-Puigpedrós només tenim constància d'una dada d'aquesta planta àrticoalpina, corresponent a una localitat de la part septentrional, dins ter- 
ritori andorrà (Carrillo et al., 2008). Es tracta d'una espècie força rara als Pirineus, que a la Catalunya autònoma només es coneixia amb seguretat del Pallars i l'Aran, mentre que més cap a l'est les localitats considerades fiables se situen a Andorra o a la Catalunya nord (Bolòs \& Vigo, 1996). Força citacions pirinenques d'aquest tàxon sembla que corresponen a confusions amb formes d'alta muntanya de $G$. sylvaticum L., com ha passat al Ripollès (Vigo, 1983), i han de ser revisades.

\section{Iberis ciliata All. subsp. ciliata}

Alt Urgell: Josa i Tuixén, vessants baixos de la Roca de Santaló, cap a Cal Patraco, CG7977, 1050-1150, pedrusques i prats secs, 3-VII-2010; la Vansa i Fórnols, vessants baixos del Roc de la Corbera, entre el coll de Bancs i Fórnols, CG7679, $1380 \mathrm{~m}$, pedruscall sobre la carretera, 23-VI-2011.

Als Prepirineus a l'est del Segre, aquesta espècie només havia estat citada en base a dos plecs d'herbari recol·lectats prop de Tuixén i prop de l'aiguabarreig del Segre i el riu de la Vansa (Vigo et al., 2003; Sáez et al., 2004), cosa que podia fer pensar que localment és molt rara o, fins i tot, que podria tractar-se d'una presència accidental com a mala herba lligada a conreus. Els darrers anys hem constatat que no és així, ja que a la vall de la Vansa fa poblacions locals extenses, molt nombroses i lligades a hàbitats naturals (prats secs pedregosos i pedrusques), segurament inadvertides fins ara per confusió amb I. amara L.

Lepidium villarsii Gren. \& Godr. susbp. villarsii

Alt Urgell: la Vansa i Fórnols, Pradell, a l'extrem oest de la serra del Cadí, CG8082, 1950-1960 m, mollera basòfila i prats veïns, 3-VII-2010.

Oròfit lligat a sòls molls i carbonatats, molt rar a Catalunya, i que als Prepirineus orientals només havia estat indicat a Prat de Cadí, a la zona central d'aquesta serra (Vigo et al., 2003). A Pradell hi feia una població localitzada però relativament nombrosa.

Linaria simplex Willd. ex Desf.

Alt Urgell: el Pont de Bar, solells sobre el poble, CG8592, 890 m, pradells terofítics en marges de camí i camps abandonats, 7-VII-2013.

Com altres tàxons comentats en aquesta nota, aquesta linària és una planta mediterrània que apareix de manera localitzada als solells de l'alt Segre. És present de manera esparsa als Prepirineus centrals, però no havia estat citada dels Pirineus axials, ni tampoc a la vall del Segre més amunt del congost d'Organyà (BDBC).

\section{Linum tenuifolium L. subsp. tenuifolium}

Alt Urgell: Josa i Tuixén, pont de Cerneres, CG8879, 1460 m, terrenys calcinals amb abundants afloraments de terra nua, 23-VI-2011; CERDANYA: Montellà i Martinet, Montellà, sobre el torrent de la font de l'Abeller, CG9488, 1320 m, talús al marge d'una pista forestal, 1320 m, 20-VI-2009; Riu de Cerdanya, serrat de les Boïgues, a l'est de la boca nord del túnel Cadí, DG0488, 1250-1260 m, marges de camí en terrenys més o menys margosos temporalment humits, 22-VI-2013. 
Tàxon molt rar a Catalunya, que arriba a algunes valls pirinenques en situació d'extrem sud d'àrea (Bolòs \& Vigo, 1990) i que està mal documentat. Pel que fa a aquest darrer aspecte, cal dir que la distribució actualment reflectida al BDBC és errònia, a causa de la barreja de dades del tàxon amb citacions de L. tenuifolium s.1. Aportem localitats que contribueixen a precisar la seva situació a la conca alta del Segre, juntament amb les dades de treballs previs (Aymerich, 2003; Vigo et al., 2003; Aymerich et al., 2008). En la nostra opinió hi ha indicis que pot ser una planta en regressió, i actualment sembla que depèn en bona part d'ambients generats per pertorbacions antròpiques, ja que dels sis nuclis poblacionals observats en els darrers temps, cinc estan lligats a aquests hàbitats. L'única població coneguda en un hàbitat plenament natural és la del pont de Cerneres, i és també la més nombrosa (centenes d'individus). És destacable el fet que a la localitat de Riu L. tenuifolium subsp. tenuifolium estava limitat als marges d'una pista forestal, mentre que als prats secs situats a pocs metres només s'hi observava L. tenuifoilum subsp. milletii.

Lythrum portula (L.) D.A. Webb

CERdanya: *Fontanals de Cerdanya, sota el poble de Queixans, DG1194, 1100 m, depressió entollada en un prat de dall, 1-X-2013.

Espècie força estesa a les zones silícies de la Catalunya oriental, però molt poc citada als Pirineus (BDBC). A la conca del Segre tan sols en coneixem una indicació a Ur (Bolòs et al., 1997), no gaire lluny de la localitat de Queixans, però ja dins l'Alta Cerdanya.

Medicago orbicularis (L.) Bartal.

Cerdanya: *Riu de Cerdanya, entre el poble i l'àrea de servei del túnel del Cadí, DG0388, 1230 m, marge d'un sembrat, 13-IX-2013.

Aquesta espècie, força banal a la Catalunya mediterrània, ha estat molt poc citada als Pirineus (BDBC). Pel que fa a l'àmbit d'aquesta nota, n'hi ha unes poques citacions a la vall del Segre fins a l'altura de la Seu d'Urgell i l'extrem sud d'Andorra (Vigo et al., 2003; Sáez et al., 2004; Carrillo et al., 2008), mentre que a la conca mitjana-alta del Llobregat tan sols sabem que hagi estat indicada en un quadrat del Berguedà (Bolòs, 1998). La població trobada a la Cerdanya presenta la particularitat de ser glanduloso-pubescent a les tiges, fulles i llegums, mentre que $M$. orbicularis és típicament glabra o glabrescent. Tot i això, la resta de caràcters es corresponen bé amb els de l'espècie. Plantes com aquestes serien excepcionals, ja que a la bibliografia consultada hem trobat ben poques referències sobre indument glandulós en $M$. orbicularis, però sembla que es pot donar ocasionalment almenys als llegums (Casellas, 1962; Sales \& Hedge, 2000) o fins i tot en fulles i tiges (Romero, 2009).

\section{Mentha arvensis L.}

Cerdanya: Fontanals de Cerdanya, sota el poble de Queixans, DG1194, 1100 m, herbassars higròfils vora una sèquia, 1-X-2013.

Aportem una localitat d'aquesta espècie a la Baixa Cerdanya i recent. Aparentment, les dades d'aquesta zona que reflecteixen les cartografies de referència 
(Bolòs et al., 2003; BDBC) són antigues i corresponents a l'Alta Cerdanya, o bé de localització imprecisa (Cadevall \& Font Quer, 1932). Bolòs \& Vigo (1996) només la reconeixen com a present a l'Alta Cerdanya, on sembla que seria molt rara, i no en consten dades recents a la base de dades en línia www.tela-botanica.org.

\section{Mercurialis huetii Hanry}

Alt Urgell: el Pont de Bar, solells sobre el poble, CG8592, 890-920 m, marges de camí i talussos de la carretera d'Aristot, 7-VII-2013.

Localitat notable d'una espècie netament termòfila, molt separada de les més pròximes fins ara conegudes, que se situarien a la franja de contacte entre els Prepirineus centrals i la depressió de l'Ebre (Bolòs et al., 1999; BDBC). D'acord amb la informació que tenim, aquesta seria la primera citació de l'espècie a les valls dels Pirineus axials, ja que tampoc no hi ha estat indicada a l'Aragó (Villar et al., 1997; López-Udias, 2013).

\section{Minuartia rubra (Scop.) McNeill}

Solsonès: Guixers, Vilasaló, vora l'embassament de la Llosa del Cavall, CG8465, 820 m, petit aflorament de roca calcària, 24-VI-2013; Sant Llorenç de Morunys, serrat de la Creueta al sud del nucli urbà, CG8365, 910 m, carenes pedregoses i marges de camí amb el sòl remenat, IX-2013.

Espècie que a Catalunya és escassa, però relativament estesa, als Prepirineus i Pirineus centrals, que ja es fa molt rara a l'est del Segre (Bolòs \& Vigo, 1990; Vigo et al., 2003; Sáez et al., 2004; Aymerich et al., 2008; BDBC) i que no sabem que hagués estat citada del Solsonès. En zones pròximes havia estat indicada dels relleus del marge esquerre de la vall del Segre (Sáez et al., 2004) i, amb certs dubtes, de Tuixén (cf. Vigo et al., 2003).

\section{Muscari baeticum Blanca \& al.}

Alt Urgell: la Vansa i Fórnols, vessant oest del Puig Galliner, 1730-1800 m, pastures xeròfiles, CG8179-8279, 29-V-2014; BERGUEDÀ: *Berga-Castellar del Riu, serrat de la Figuerassa, DG0263-0363, 1360-1490 m, prats xeromesòfils i calcícoles de carena, 20-VI-2013; Capolat, Cap dels Plans, CG9258-9358, 1300$1360 \mathrm{~m}$, prats xeromesòfils de carena i codines de conglomerats, 20-VI-2013; CERDANYA: Alp, la Pia, DG1088, 1690 m, pastures mesoxeròfiles calcícoles, 23V-2014; Urús, serrat de les Pedrusques, roc de l'Orri, DG0787, 1930 m, prat xeromesòfil en una carena calcària, 26-VI-2013; Bellver de Cerdanya, solells del serrat de la Farg Vella, CG9992-9993, 1150-1510 m, pastures xeròfiles i xeromesòfiles sobre calcàries, 24-V-2014; soLsonès: Guixers, coll de Jou, CG7966, 1460 m, codines en conglomerats, 24-VI-2013; Navès, altiplà de Busa, CG86618761, 1400-1440 m, prats xeromesòfils sobre conglomerats, 20-VI-2013.

Després dels estudis de Suárez-Santiago et al. (2007) es fa necessària una revisió dels coneixements sobre la distribució dels tàxons que tradicionalment havien estat inclosos en $M$. neglectum s.l. En aquest sector pirinenc l'hàbitat principal d'aquestes plantes són les pastures seques i més o menys pedregoses de carena (Vigo et al., 2003), on sovint fan poblacions nombroses i extenses. Es 
tracta d'ambients amb un cert grau de pertorbació edàfica a causa de la crioturbació i de la pressió ramadera, però que en general tenen poca influència antròpica. L'anàlisi d'algunes d'aquestes poblacions ha posat de manifest que en tots els casos es tracta de $M$. baeticum, una espècie oròfila de la Mediterrània occidental, i no pas de $M$. neglectum en sentit estricte, tàxon que segons SuárezSantiago \& Blanca (2013) està bàsicament lligat a hàbitats agraris. M. baeticum ja havia estat assenyalat dels Pirineus catalans per Suárez-Santiago \& Blanca (2013), precisament en base a un parell de plecs d'herbari de l'àmbit geogràfic considerat en aquesta nota, i considerem que es pot assumir que hi corresponen totes o la gran majoria de les nombroses poblacions existents a les pastures i roquissars de muntanya.

\section{Ononis fruticosa L.}

BERGuedÀ: Saldes, vessant nord de la serra d'Ensija, torrent de Roques Blanques, CG9573, 1500 m, xaragall en terreny argilós, 16-III-2008.

Nova localitat d'aquesta espècie a l'alt Llobregat, on fins ara només es coneixia de diversos indrets de la rodalia de Bagà (Soriano, 1984; Vigo et al., 2003).

Papaver lapeyrousianum Gutermann ex Greuter \& Burdet

Alt Urgell: les Valls de Valira, Bescaran, vessant sud del Monturull, CH8300, $2700 \mathrm{~m}$, tartera d'esquistos, 2-VIII-2013.

Espècie que gairebé no ha estat citada d'aquest sector pirinenc, en el qual només tenim constància d'una indicació una mica més al nord-est, cap a Setut i aparentment dins territori andorrà (Carrillo et al., 2008). Al Monturull només hi vam veure unes poques desenes d'individus.

Persicaria hydropiper (L.) Delarbre [Polygonum hydropiper L.]

Cerdanya: Bellver de Cerdanya, riberal del Segre cap al Prat de Codina, CG9891, 1000 m, vores d'una sèquia, 9-IX-2013; Bellver de Cerdanya, torrent de la Bavosa prop de l'aiguabarreig amb el Segre, DG0191, 1020 m, herbassar higròfil, 9-IX2013; Bolvir, àrea entre Mas Arbó i la Molina de Bolvir, DG0795-0894-08950994-0995, 1070-1090 m, força freqüent en vores de sèquies i herbassars higròfils, VIII a X-2013; Isòvol, ribera del Segre al sud del santuari de Quadres, DG0493, 1040 m, herbassar higròfil, 13-IX-2013; Fontanals de Cerdanya, riberal del Segre al voltant de Queixans i les Pereres, DG1094-1194-1195, 1100 m, frequient a les sèquies dels prats de dall, 19-IX-2013; Ger, riberal del Segre entre el Molí de Ger i el Salitó, DG0594-0694, 1055-1060 m, presència intermitent en sèquies i depressions temporalment inundades, 28-X-2013.

Aquesta planta ha estat molt poc citada dels Pirineus més a l'oest del Ripollès (BDBC), i de l'alt Segre només en coneixem una indicació a la Cerdanya, concretament a Alp (Bolòs et al., 1988). D'acord amb les observacions que aportem, estaria més o menys estesa a les zones aigualoses de la plana cerdana, bé que hi és local i en general escassa. 
Persicaria minor (Huds.) Opiz. [Polygonum minus Huds.]

Cerdanya: *Bolvir, el Palancó, al nord de Talltorta, DG0995, 1090 m, terreny semiinundat, amb jonqueres i prat de dall, 22-VIII-2013. Fig. 2.

D'acord amb la informació disponible, aquesta espècie és nova per a la flora de Catalunya. N'existiria un plec (MAF 43601) sense data ni recol-lector, amb etiqueta de la Puda de Montserrat, localitat força inversemblant, que va ser citat per Villar (1987) com de «procedència dubtosa», i aquest mateix autor ja no el va tenir en compte a Flora iberica (Villar, 1990). Les citacions antigues de Costa (1887) al baix Llobregat han estat considerades errònies i no s'han acceptat en les flores modernes (Bolòs \& Vigo, 1990; Villar, 1990; Bolòs et al., 2005). Villar (1990) sí que l'assenyala de la província de Lleida, en base a una referència bibliogràfica no concretada; suposem que aquesta indicació pot derivar de citacions antigues en territori d'administració francesa prop de l'Aran, que van ser recollides per Cadevall \& Font Quer (1933) dient que es troba «probablement a la Vall d'Aran». Es tracta d'una planta eurosiberiana que es fa rara cap al sud-oest d'Europa i que ha estat citada escassament al sud de França i al nord i oest de la península Ibèrica (Villar, 1990; www.tela-botanica.org). Les localitats modernes més pròximes se situarien a la vall mitjana de la Garona (www.tela-botanica.org). A la nova localitat de la Cerdanya hi vam observar unes quantes desenes d'individus reproductors, concentrats en una superfície de menys de $10 \mathrm{~m}^{2}$. Es trobaven a la perifèria d'una parcel-la que ha estat roturada ocasionalment i que és utilitzada com a prat de dall.

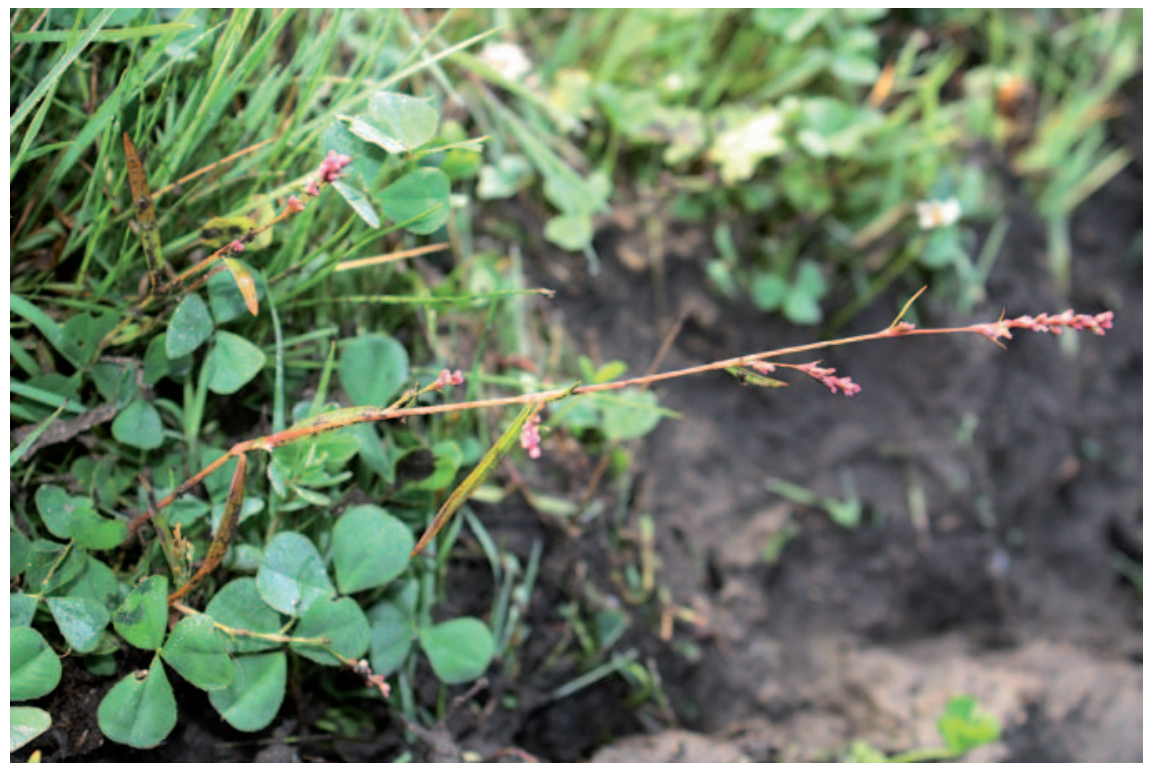

Figura 2. Persicaria minor a la localitat de Bolvir (Cerdanya). 


\section{Potamogeton berchtoldii Fieber}

Cerdanya: Bellver de Cerdanya, Santa Eugènia, cap a Cal Pubill, CG9691, 985 m, basses marginals del riu Segre, en companyia de Lemna minor i Callitriche sp., 21-V-2011; Das, ribera del Segre sota Sanavastre, DG0493, 1045 m, sèquia, en companyia de Callitriche sp., 2011-2012; Das, bassa de Sanavastre, DG0592, 1050 m, estanyol artificial creat per una extracció de carbó a cel obert, en companyia de diversos hidròfits, 1991-2013; la Guingueta d'Ix, Mas Blanc, DG1399, 1150 m, gran bassa artificial, en companyia de Ceratophyllum demersum, Lemna minor i Callitriche sp., Isòvol, pla d'Isòvol, DG0392, 1030 m, dues petites basses generades per extracció d'àrids, en companyia de Lemna minor, Callitriche sp. i alguns anys, de Groenlandia densa, Ranunculus sp. i Polygonum amphibium, 2003-2012; Prats i Sansor, aigües amunt de l'estret d'Isòvol, DG0292, 1030 m, canal paral-lel al riu Segre, 16-X-2012.

Es tracta d'un hidròfit relativament estès a la plana de Cerdanya, en altituds al voltant dels 1000 m, tot i que hi està poc documentat (cf. BDBC). La seva detecció és dificultada pel fet que tendeix a fer poblacions temporals o d'abundància fluctuant, així com per les possibles confusions si no s'observen plantes reproductores. A Catalunya es troba sobretot als estanys d'alta muntanya dels Pirineus (Bolòs \& Vigo, 2001; BDBC) i és molt rar per sota dels 1500 m.

\section{Potentilla frigida Vill.}

Cerdanya: *Lles de Cerdanya, Vallcivera, vessant nord del pic de la Muga, CH9103, 2800 m, sòl esquelètic sobre roques silícies, 31-VII-2013.

D'aquesta espècie en coneixem tres indicacions prèvies al conjunt del sector Tosa Plana-Puigpedrós, però sembla que totes quedarien fora del límit administratiu de la Catalunya autònoma, a diferència de la que ara aportem. La presència al quadrat CH90, recollida al BDBC, derivaria d'una citació a Campquerdós, ja dins zona d'administració francesa (Gruber, 1978). Dues altres citacions del quadrat adjacent $\mathrm{CH} 80$ corresponen una al vessant obac de la Tosa Plana i l'altra també hauria de ser de la Tosa Plana per l'altitud de 2900 m que es dóna; per l'exposició indicada, la primera localitat s'ha de situar necessàriament dins territori andorrà, i també és altament probable que hi estigui la segona. Malgrat aquestes citacions a la Tosa Plana, a la base de dades de biodiversitat d'Andorra (www.siba.ad) $P$. frigida només apareix indicada en un parell de quadrats del nord del territori, i es considera que hi és una espècie amenaçada (Carrillo et al., 2008).

\section{Ranunculus carlittensis (Sennen) Grau}

Cerdanya: Bellver de Cerdanya, Santa Eugènia, cap a Cal Pubill, CG9691, 985 m, 21-V-2011; Ger, riba esquerra del riu Segre, DG0694, 1055 m, verneda, 24-IV-2013; Isòvol, Prades de Segre, DG0594, 1050 m, verneda, 24-IV-2013; Meranges, riu Duran sobre Girul, CH9800, 1630 m, marges del riu, 23-V-2013; Prullans, la Riberola, CG9591, $980 \mathrm{~m}$, verneda, 17-IV-2011.

Aquest tàxon del grup de $R$. auricomus està poc documentat amb citacions precises, tot i que sembla estès als Pirineus catalans. A la Cerdanya és força ca- 
racterístic de les vernedes eutròfiques del riu Segre, on és localment abundant, però pot ser inadvertit a causa de la seva floració primerenca, prèvia al desenvolupament d'herbassars densos de plantes de tendència nitròfila.

Rorippa sylvestris (L.) Besser

Alt Urgell: Estamariu, ribera del Segre entre Torres d'Alàs i la Quera, CG7990, 730 m, sòl sorrenc a la la llera del riu, 3-X-2013. CERdanya: Das, Sanavastre, DG0493, 1040 m, recs exundats vora el Segre, 11-XI-2011; Fontanals de Cerdanya, riberal del Segre a l'oest del Camp de Golf de Fontanals, DG0694, 1060 m, depressions temporalment inundades i més o menys nitrificades, 16-X-2012; Ger, riberal del Segre al Molí de Ger, DG0694, 1060 m, depressions temporalment inundades, 28-X-2013; Ger, riberal del Segre al Salitó, DG0594, 1055 m, fangars exundats vora el riu i depressions temporalment inundades en clarianes de verneda, 28-X-2013.

L'àrea catalana d'aquesta espècie abasta sobretot les comarques humides del nord-est, mentre que a les valls dels Pirineus centrals només hi apareix de forma molt puntual (Bolòs \& Vigo, 1991; Bolòs et al., 1997; BDBC). No ens costa que hagués estat citada de l'alt Segre, on és certament rara, bé que potser també ha estat inadvertida a causa de la seva floració tardana.

Salix $x$ abnormis Rouy [S. pyrenaica Gouan x S. elaeganos Scop.]

Alt Urgell: Cava, vessant nord de la serra del Cadí, canal Baridana, CG8783, 2100 m, tartera calcària, amb presència a pocs metres de les dues espècies parentals, 9-VIII-2013; Cerdanya: Montellà i Martinet, vessant nord de la serra del Cadí, sot de les Llobateres, CG9283, 1860 m, terreny rocallós calcari amb surgència d'aigua, espècies parentals absents en un radi de 50 m, 11-VIII-2007 (P. Aymerich, herb. pers.).

No tenim coneixement de citacions a Catalunya d'aquest salze, que no és recollit a la llista d'híbrids de Bolòs \& Vigo (1990). Descrit per Rouy del vessant nord dels Pirineus centrals, a Gavarnia (Baranda, 1984), és acceptat com a existent a la península Ibèrica per Blanco (1993), però sorprenentment tampoc no és citat al Pirineu aragonès (Mercadal, 2013), on les dues espècies parentals són abundants. De les dues localitats indicades del Cadí, a la primera es presentava en forma d'un individu isolat, mentre que a la segona havia constituit una petita població d'una vintena d'individus.

\section{Saxifraga retusa Gouan}

Cerdanya: *Lles de Cerdanya, Vallcivera, vessant nord del pic de la Muga, CH9103, 2800 m, fissures de roques silícies, en exposició nord, 31-VII-2013.

Nova localitat d'aquesta rara espècie al sector pirinenc Tosa Plana-Puigpedrós, on ha estat indicada d'uns pocs indrets, sobretot a Andorra (www.siba.ad). Resulta dubtós si en aquest sector se'n coneixia cap localitat estrictament situada dins la Catalunya autònoma, ja que les dues indicacions que el BDBC assenyala als quadrats CH80 i CH90 sembla que estarien al costat nord de la carena, per pocs metres dins territori administratiu andorrà i francès respectivament; pel que 
fa al quadrat $\mathrm{CH} 90$, podem confirmar que se situa en zona d'administració francesa una dada pròpia reflectida al BDBC de la zona de carena del massís del Puigpedrós (entre la portella de Meranges i el pic de Puigpedrós, CH9705, 2750 m). En canvi, la nova localitat de Vallcivera està inequívocament dins els límits de la Catalunya autònoma. Botànicament, aquesta adscripció administrativa de les citacions és irrellevant, però ho destaquem perquè té un cert interès pràctic per a la gestió de la biodiversitat.

\section{Scrophularia auriculata L. subsp. auriculata}

RIPOLLÈs: Toses, riu Rigard entre Planès i Nevà, DG2485, 1090 m, herbassars vora l'aigua, 2-XII-2012.

Ampliem al Ripollès occidental l'àrea d'aquest tàxon als Pirineus catalans, on havia estat inadvertit fins fa poc (Aymerich, 2013c).

\section{Sedum annuum L.}

Cerdanya: Lles de Cerdanya, entre les Pollineres i l'estany Petit de la Pera, CH8500, 2230 m, sòl pedregós silici en un marge de prat, 2-VIII-2013; Lles de Cerdanya, vessant sud de la Tosa Plana, a l'oest del clot de l'Orri, CH8900, 2450 m, pradell en sòl silici pedregós, 31-VII-2013.

Espècie comuna als Pirineus silicis que, sorprenentment, sembla que no havia estat citada de l'ampli sector pirinenc entre els rius Segre i Valira (BDBC). N'aportem un parell de localitats d'aquest sector, on suposem que deu estar més estesa del que indica la informació publicada.

Senecio doria L. subsp. doria

Solsonès: Odèn, Canalda, CG7764, 1220 m, herbassar humit vora una surgència, 15-VII-2013.

Espècie en general escassa a Catalunya i molt rara a l'est del riu Segre (Bolòs \& Vigo, 1996). En aquest sector prepirinenc havia estat indicada de Sant Llorenç de Morunys per Vives (1964), on no ha estat retrobada, i més endavant d'una localitat de la vall de la Vansa (Vigo et al., 2003).

\section{Silene conica $\mathrm{L}$. subsp. conica}

Alt Urgell: Montferrer i Castellbò, ribera del Segre, CG7188, 655 m, prat sec en un codolar fluvial apartat del riu, 13-VII-2013 (en fruit).

Espècie molt rara a les valls pirinenques, escassament citada de la Ribagorça, del Pallars i de l'Alt Urgell (BDBC). La citació més pròxima és de Fígols d'Organyà, Segre avall i ja en l'àmbit dels Prepirineus (Sáez et al., 2004).

\section{Silene muscipula $\mathrm{L}$.}

Alt Urgell: el Pont de Bar, solell de la Roca Sombra, CG8391, 950 m, camí entre antigues feixes, 7-VII-2013.

A Catalunya aquesta planta es concentra a la meitat sud i gairebé no ha estat indicada de l'àmbit pirinenc, on el BDBC en recull una sola dada dels Prepirineus del Solsonès (Vives, 1964). No seria estrany que als Pirineus només hi aparegui 
de manera accidental, considerant que al Pont de Bar vam trobar un sol individu i que Vives (1964) la va observar en un marge de carretera.

\section{Silene nocturna L.}

Alt Urgell: Montferrer i Castellbò, urbanització Balcó del Pirineu, CG7088, $750 \mathrm{~m}$, talussos assolellats enmig de zones residencials, 13-VII-2013; el Pont de Bar, solells sobre el poble, CG8592, 890 m, pradells terofítics en marges de camí i camps abandonats, 7-VII-2013.

Localitats de la vall del Segre intermèdies entre les ja conegudes per a aquesta espècie als voltants d'Organyà i de Martinet (Vigo et al., 2003; Sáez et al., 2004). És probable que en aquesta zona sigui més freqüent del que s'havia pensat, ja que els solells càlids potencialment favorables abunden entre la Seu d'Urgell i Bellver.

Sisymbrella aspera (L.) Spach subsp. aspera

Alt Urgell: el Pont de Bar, collet de Sorri, CG8293, 1490 m, depressió humida, 13-VII-2013; Cerdanya: Fontanals de Cerdanya, al sud de Soriguera, DG0894, 1090 m, rasa de desguàs d'un camp, enmig d'un poblament d'Alisma lanceolatum, 21-VII-2013.

Aportem dues localitats d'aquesta espècie a l'alta vall del Segre, on gairebé no ha estat citada fora de les serres prepirinenques (BDBC).

Sisymbrium macroloma Pomel

Alt Urgell: *el Pont de Bar, Aristot, marges de carretera als afores del poble, CG8692, 1220-1230 m, peu de talussos rocosos i nitrificats arran de carretera, 13-VII-2013; CERdanya: Riu de Cerdanya, serrat de les Esposes, balma de Segalers, DG0386, 1480 m, gran balma freqüentada pel bestiar, 23-V-2014.

Espècie molt rara a la Catalunya autònoma, on tot just ha estat citada d'unes poques localitats pirinenques de la vall de Ribes i de l'alt Berguedà (Vigo, 1983; Soriano, 1993; Vigo et al., 2003) i, a les muntanyes prelitorals, d'una de la serra del Montsant (Pascual, 2007) i en algun punt del massís dels Ports (Alvarez de la Campa, 2004). És freqüient, en canvi, als Pirineus aragonesos (Villar et al., 1997), per on arriba fins al límit administratiu amb Catalunya. L'hàbitat de la població ara trobada a l'Alt Urgell resulta força atípic, perquè és una planta molt lligada a balmes frequientades pel bestiar, però les condicions ecològiques bàsiques (peus de roca i sòls nitrificats) dels llocs on apareix a Aristot són en certa manera similars a les d'aquelles balmes. Per contra, la població de la Cerdanya té un hàbitat ben típic, com les que ja es coneixien al vessant berguedà de la mateixa serra del Moixeró (Soriano, 1993).

\section{Solanum villosum Mill.}

BERGuedÀ: Avià, riba dreta del Llobregat sota el Lledó, a l'altura de la Colònia Rosal, DG0657, 480 m, herbassar ruderal, X-2013; Puig-reig, Colònia Marçal, DG0745, 390 m, herbassar ruderal, 17-XI-2013.

Espècie que ha estat molt poc citada fora de les franges litoral i prelitoral de Catalunya (BDBC). Dins l'àmbit d'aquesta nota només en coneixem una citació 
a l'alt Solsonès (Devis, 2006) i una indicació poc concreta a l'Alta Cerdanya (Bolòs \& Vigo, 1996). Fora d'aquest àmbit, les citacions més pròximes a la conca del Llobregat se situen a l'extrem sud del Bages, mentre que a la del Segre n'hi ha algunes a la conca mitjana (Bolòs \& Vigo, 1996; Bolòs et al., 2003; BDBC). A les localitats del Berguedà que reportem hi vam observar pocs individus (una trentena a Puig-reig i menys de deu a Avià), que creixien barrejats amb S. nigrum. Les plantes de totes dues poblacions corresponien a les formes de tija angulosa $\mathrm{i}$ sense indument glandular, que algunes vegades han estat anomenades subsp. miniatum (Bernh. ex Willd.) Edmonds o var. miniatum (Bernh.) Fries, bé que actualment es consideren sense valor taxonòmic; segons Bolòs \& Vigo (1996) aquestes formes miniatum pràcticament no haurien estat citades de l'interior català, llevat d'alguna dada del territori sicòric.

\section{Spergula morisonii Boreau}

Cerdanya: *Ger, Gréixer, entre els serrats de la Ginebreda i de les Llebres, DG0297, $1530 \mathrm{~m}$, pradells terofítics en un aflorament planer de roca silícia, 23-V-2013.

Planta distribuïda de manera molt esparsa a les muntanyes del nord de Catalunya i que ha estat poc citada (Bolòs \& Vigo, 1990; Bolòs et al., 2000, BDBC). La informació de la Cerdanya reflectida al BDBC és imprecisa i sembla basada en algun plec d'herbari antic. Amb aquesta nota aportem una localitat concreta $\mathrm{i}$ recent de l'espècie a la comarca.

Spergularia segetalis (L.) G. Don

Cerdanya: *Bolvir, Roca de Tirallonga, DG0798, 1250 m, pradells terofítics temporalment molls en substrat silici, acompanyant Juncus bufonius, 17-VII-2013.

La presència d'aquesta espècie a la Cerdanya és coneguda des de fa temps (Bolòs \& Vigo, 1990), però està mal documentada, fins al punt que el BDBC no en dóna cap localització precisa. Fora de la Cerdanya, a Catalunya només es coneix de les muntanyes de Prades (Masclans \& Batalla, 1972; Molero, 1984).

Stellaria neglecta Weihe

Cerdanya: Ger, riba esquerra del riu Segre, DG0694, 1055 m, marges de camins dins una verneda, 13-VI-2013.

Espècie no citada fins ara de la vall del Segre i en general molt rara als Pirineus catalans (BDBC). Les poblacions més pròximes conegudes es troben a l'alt Ripollès.

Trifolium hybridum L.

CERdanya: Bellver de Cerdanya, torrent de la Bavosa prop de l'aiguabarreig amb el Segre, DG0191, 1020 m, herbassar higròfil, 9-IX-2013; Bolvir, cap als Platers, DG0995, 1110 m, prats mesohigròfils, 28-X-2013; Bolvir, entre el Mas Aravó i el Club de Golf Cerdanya, DG0995, 1090 m, prat de dall inundat amb taques de jonquera, 17-VII-2013; Bolvir, cap a l'aiguabarreig dels rius Segre i Querol, DG0994, 1080 m, depressió temporalment inundada, 2-IX-2013; Bolvir, cap a la 
Molina de Bolvir, DG0795, 1070 m, clarianes de verneda amb herbassars higròfils, 16-X-2013; Fontanals de Cerdanya, Soriguerola, la Zona, DG0694, 1060 m, prat de dall temporalment inundat, 2-IX-2013; Fontanals de Cerdanya, les Pereres, a l'est del Mas de Montagut, DG1295, 1150 m, prat mesòfil, 2-IX-2013; Ger, riberal del Segre al Molí de Ger i a la Riberola, DG0594-0694, 1055-1060 m, depressions temporalment inundades a la perifèria dels prats de dall, 28-X-2013; Isòvol, ribera del Segre al sud del santuari de Quadres, DG0493, 1040 m, herbassar higròfil, 13-IX-2013; Isòvol-Prats i Sansor, ribera del Segre per damunt del congost d'Isòvol, en totes dues ribes del riu i en una illeta fluvial, DG0291-0292, 1025-1030 m, herbassars higròfils en zones temporalment inundades, 16-X-2012 i 17-VII-2013; Prats i Sansor, cap al molí de Prats, DG0392, 1030 m, jonquera nitrificada, 16-X-2012; CERDANYA-RIPOLlÈs: Alp-Toses, entorn de la collada de Toses, DG1687, $1780 \mathrm{~m}$, talussos de carretera, 21-VII-2013.

Aportem algunes localitzacions concretes d'aquesta espècie, documentada amb poca precisió al BDBC, en què tot just se citen dues localitats. És una espècie rara a Catalunya, només coneguda de la Cerdanya, on ja es va trobar al segle XIX (Cadevall, 1919). És probable que els diversos nuclis observats cap a la collada de Toses siguin el resultat d'una introducció recent, deguda al transport de terres o a sembres de talussos. En general, les poblacions són referibles a la subespècie o varietat típica, i es fan bàsicament en herbassars aigualosos, que semblen l'hàbitat normal a la zona. Només en dues localitats (Bolvir, els Platers; Fontanals, les Pereres) les plantes tenen caràcters assignables al que s'ha anomenat subsp. elegans (Savi) Asch. \& Graebn. [var. elegans (Savi) Boiss.; T. elegans Savi], i alhora són les dues úniques poblacions que viuen en hàbitats una mica diferents (prats mesòfils). El tractament taxonòmic de les plantes amb caràcters «elegans» ha estat divers, bé que la tendència de moltes flores europees és acceptar que constitueixen una subespècie. Bolòs \& Vigo (1984) esmenten les dues varietats, però no queda clar si les dues han estat observades a Catalunya.

\section{Trifolium retusum $\mathrm{L}$.}

Cerdanya: *Das, ribera del Segre a Sanavastre, DG0594, 1050 m, enmig d'un camí poc transitat, 13-VI-2013.

Tot i que aquesta espècie és coneguda des del segle Xıx a la Cerdanya, sembla que en manquen dades modernes concretes, i que la informació en la qual es basarien les síntesis corològiques (Bolòs \& Vigo, 1984; Bolòs, 1998; BDBC) són les citacions de Companyó recopilades per Cadevall (1919). Amb aquesta nota confirmem la seva presència actual a la Cerdanya. La població trobada a Sanavastre era molt localitzada, però densa i amb una gran quantitat d'individus. Es tracta d'un tàxon molt rar a Catalunya, citat esparsament dels Pirineus de clima continental (Carreras, 1993; Ninot et al., 2010) i, de manera isolada, de les muntanyes de Prades (Molero, 1982).

\section{Trifolium sylvaticum Gérard}

Cerdanya: Guils de Cerdanya, serra dels Fills, DG0798, 1290 m, prats terofítics en substrat silici, 17-VII-2013. 
Aquest trèvol, que té una àrea fragmentada a Catalunya, no apareix indicat a la Cerdanya al BDBC, però sí que hi és citat vagament per Bolòs \& Vigo (1984). Es fa més present cap a l'oest, en zones seques dels Pirineus de l'Alt Urgell i del Pallars.

\section{Veronica dillenii Crantz}

Cerdanya: *Meranges, cap a Sant Josep, en diversos llocs, DG0197-0297, 1580$1600 \mathrm{~m}$, pradells terofítics entre matollars de bàlec i marges de sembrat, 23-V-2013.

Teròfit molt rar a Catalunya, localitzat en alguns indrets dels Pirineus de la Cerdanya i del Ripollès i al massís del Montseny. Aparentment, aquesta seria la primera citació a la Baixa Cerdanya, ja que no hi és assenyalada per Bolòs \& Vigo (1996), mentre que les dades reflectides a les síntesis corològiques posteriors (Bolòs et al., 2004; BDBC) serien força antigues i de l'Alta Cerdanya, fora de l'àmbit administratiu de la Catalunya autònoma.

\section{Viola diversifolia (Ging.) W. Becker}

Alt Urgell - Cerdanya: les Valls de Valira (Bescaran)-Lles de Cerdanya, línia de carena des del Monturull fins al Turó Punçó, CH8300-8400 i CG8497-84988499, 2430-2700 m, presència intermitent a les tarteres esquistoses, VIII-2013.

Aquest endemisme pirinenc no és citat del sector Tosa Plana-Puigpedrós per Bolòs et al. (1998) ni al BDBC. Tot i això, es coneix des de fa un temps la seva presència en aquest sector dins territori andorrà, a l'àrea Pic Negre-Calm de Claror (Carrillo et al., 2008; www.siba.ad; dades pròpies). Les localitats que aportem dins la Catalunya autònoma es poden considerar la continuació cap al sud-est d'aquesta àrea andorrana. Localment és una planta freqüent i abundant, segurament inadvertida fins ara per manca de prospecció florística en aquest sector pirinenc, com ha passat amb Papaver lapeyrousianum i Xatardia scabra, espècies que viuen en els mateixos hàbitats però que hi són molt més escasses.

Xatardia scabra (Lapeyr.) Meisn.

Alt Urgell: les Valls de Valira, Bescaran, vessant sud del Monturull, CH8300, 2700 m, tartera d'esquistos, 2-VIII-2013; les Valls de Valira, Bescaran, vessant sud de la serra Airosa, CH8400, 2610 m, tartera d'esquistos, 2-VIII-2013.

Noves localitats d'aquest endemisme dels Pirineus catalans, que a l'ampli sector Tosa Plana-Puigpedrós només havia estat citat de dos indrets de la capçalera del riu Duran (Nuet, 1998). En aquesta nova zona l'hem vist escàs, amb unes quantes desenes d'individus en conjunt, i al Monturull només hi vam trobar individus no reproductors.

\section{Tàxons al-lòctons}

Acer saccharinum L.

Alt Urgell: Montferrer i Castellbò, riu Segre sota l'aiguabarreig amb el riu Valira, CG7189, 655 m, illeta fluvial amb predomini de vegetació herbàcia, 3-X-2012. 
Arbre originari de l'est d'Amèrica del Nord, que és sovint cultivat en jardineria i que a Europa es presenta ocasionalment com a escapat, per exemple a Anglaterra i a França (www.brc.ac.uk/plantatlas/; www.tela-botanica.org). En aquesta localitat de l'Alt Urgell vam observar un sol individu d'uns $6 \mathrm{~m}$ d'alçada. La indicació més pròxima que coneixem d'aquesta planta en estat salvatge correspon al Llenguadoc, departament de l'Aude (www.tela-botanica.org).

\section{Achillea filipendulina Lam.}

Solsonès: Sant Llorenç de Morunys, CG8365, 940 m, camp abandonat en una zona suburbana, 15-VII-2013.

Herba originària de l'oest d'Àsia, que es cultiva com a ornamental i tendeix a naturalitzar-se, generalment en ambients suburbans i viaris. Està ben implantada al centre de la península Ibèrica (Sanz et al., 2004), però a Catalunya només en tenim coneixement d'una citació (Pedrol et al., 2002), d'una població en un marge de camí, de la Noguera. Tot i això, l'aparició d'aquesta planta amb caràcter casual podria ser més freqüent del que suggereixen les dades publicades, ja que a l'herbari BCN n'hi ha almenys dos plecs que no correspondrien a individus cultivats: BCN2958 (Baix Llobregat, entre Cervelló i la Palma, 1986, leg. J.M. Ninot \& E. Carrillo) i BCN43673 (Anoia, Prats de Rei, la Manresana, 2000, leg. I. Soriano); de l'àmbit d'estudi d'aquest article n'hi ha un plec procedent de la Seu d'Urgell, Castellciutat (BCN2957, 1994, leg. X. Font), que desconeixem si és de plantes cultivades o subespontànies. A la localitat que ara aportem del Solsonès hi vam observar una vintena d'individus reproductors, $i$ hem vist aquesta espècie cultivada en diversos jardins del municipi.

Arabis alpina L. [formes cultivades; cf. subsp. caucasica (Willd.) Briq.] BerguedÀ: Castellar de n'Hug, coll de la Creueta, DG1783, 1925 m, talús de carretera, 22-VII-2013; RIPOLLÈs: Toses, carretera de Castellar de n'Hug a la Molina, sobre el torrent de la Creueta, DG1684, 1850 m, talús de carretera, 22-VII-2013.

Arabis alpina és una planta àrtico-alpina d'àmplia distribució i amb una notable variabilitat morfològica, en la qual algunes vegades s'han distingit tàxons infraespecífics de validesa discutida. Tot i que la tendència recent és considerar-la una sola espècie polimòrfica, les seves diverses poblacions i les d'espècies molt afins constitueixen un grup complex la taxonomia del qual resta pendent d'una resolució satisfactòria (Koch et al., 2006; Karl et al., 2012). Un dels tàxons infraespecífics que més sovint ha estat acceptat és la subsp. caucasica (Willd.) Briq. (A. caucasica Willd.), d'àrea suposadament oriental i meridional, i al qual també serien similars algunes poblacions del sud de la península Ibèrica (Talavera, 1993). Amb independència de la validesa d'aquesta subespècie, les plantes que tenen les seves característiques han estat el principal origen de les varietats d' $A$. alpina cultivades en jardineria, que ocasionalment s'han naturalitzat fora de la seva àrea d'origen (exs. Verloove, 2006; Pysek et al., 2012). Als talussos de la carretera de Castellar de n'Hug a la Molina hi hem observat dues poblacions aparentment consolidades d'A. alpina, d'aspecte marcadament diferent de les autòctones 
al territori i que tindrien el seu origen en les sembres artificials que cap a l'any 2000 van donar origen a l'aparició de Cerastium tomentosum — comentat més avall- i d'altres al-lòctones. Seguint els criteris de Cullen et al. (2011) aquestes poblacions semblarien referibles a A. alpina subsp. caucasica per les rosetes basals nombroses, les fulles blanquinoses amb indument molt dens, el nervi mitjà molt marcat de les valves de les silíqüies i les llavors clarament alades —ala en general 0,2,-0,3 mm, no c. $0,1 \mathrm{~mm}$ com seria normal en les poblacions ibèriques segons Talavera (1993)—; en canvi, no concorden amb la subsp. caucasica per la longitud modesta de les silíquies (fins a $4 \mathrm{~cm}$, no pas 4-7 cm). Deixem constància de l'existència d'aquestes plantes naturalitzades i diferents de les A. alpina autòctones, sobretot per ajudar a interpretar possibles observacions futures en hàbitats naturals apartats de la carretera, en cas d'una eventual expansió que per ara no hem constatat.

Aubrieta columnae Guss.

RiPOLLÈs: *Toses, carretera de Castellar de n'Hug a la Molina, sobre el torrent de la Creueta, DG1684, 1850 m, talús de carretera, 22-VII-2013.

Dos únics peus d'una crucífera del gènere Aubrieta van ser localitzats per Anna Ribera Crusafont i José Vicente Ferrández Palacio en un talús revegetat artificialment, en el qual també es fan l'Arabis alpina citada més amunt i Cerastium tomentosum; a diferència d'aquestes dues altres espècies, però, Aubrieta no havia establert al talús poblacions naturalitzades. Analitzant les mostres, i seguint els criteris de Cullen et al. (2011), es va veure que no corresponien a A. deltoidea, l'espècie que es considera més habitual en jardineria, sinó a A. columnae. Les dues espècies es distingeixen sobretot perquè la segona només té pèls estelats a les silíqües, mentre que la primera en té d'estelats i de simples, aquests més llargs. A. columnae és una planta oròfila originària del sud-est d'Europa (Itàlia i Balcans) que es cultiva com a ornamental. Ha estat citada com a puntualment naturalitzada en ambients suburbans a Bèlgica (Verloove, 2006), i no rarament s'ha confós amb A. deltoidea. Aquesta altra espècie ha estat bastant més citada com a naturalitzada arreu d'Europa - per exemple, està molt estesa en parets i camins a la Gran Bretanya (www.brc.ac.uk/plantatlas/) — i també havia estat indicada vagament amb aquest caràcter a la península Ibèrica, però va ser-ne exclosa explícitament arran de la revisió feta per a Flora iberica (Batarda, 1992). Plantes cultivades que hem vist dins l'àmbit geogràfic d'aquesta nota (Sant Llorenç de Morunys) també corresponen a A. columnae.

Berberis aquifolium Pursh. [Mahonia aquifolium (Pursh.) Nutt.]

Cerdanya: Guils de Cerdanya, Campllong, entre Guils i Saneja, DG0899, 1280 m, marge d'un camí agrícola, 1-X-2013.

Planta nord-americana cultivada com a ornamental i que es naturalitza progressivament a Europa, bé que a Catalunya només se'n coneixen unes poques dades com a subespontània. Casasayas (1989) recull l'observació d'un individu en un marge de carretera del Vallès, i nosaltres també l'hem vist subespontani en jardins abandonats del Berguedà (Aymerich, 2013d: Graugés, Avià, UTM DG05). 
La nova indicació de la Cerdanya seria similar a la del Vallès i correspon a un sol individu casual, probablement arribat per abocament de restes de jardineria.

\section{Bunias orientalis L.}

Cerdanya: Bellver de Cerdanya, entre Santa Eugènia i Pi, CG9690-9790, 1010 m, prats de dall, 24-V-2014.

Segons la informació disponible, es tracta de la primera citació a Catalunya d'aquesta planta presumptament originària del Caucas, que des del segle XIX s'ha estès molt als hàbitats antròpics de gran part d'Europa, el centre d'Àsia i Amèrica del Nord (http://www.cabi.org). En coneixem una sola localitat prèvia a la península Ibèrica, a la vall de Pineta (Pirineus aragonesos), on va ser localitzada l'any 1973 (Villar \& Montserrat, 2000) i no hi va ser retrobada fins al 2006 (Gómez, 2013). A banda d'aquesta localitat aragonesa, les dades més pròximes a Catalunya corresponen als departaments francesos d'Arieja i Aude, bé que es tracta d'una espècie que a França es troba sobretot al nord i a l'est (www.tela-botanica.org). A Bellver de Cerdanya hi hem observat uns pocs individus (menys de deu reproductors) dins dos prats de dall pròxims — un hàbitat freqüent d'aquesta espècie allà on ha estat introduïda - i sembla que hi ha aparegut fa molt poc, ja que hem visitat anualment aquests llocs en la darrera dècada i mai abans no l'havíem vista.

\section{Catalpa bignonioides Walter}

Alt Urgell: Alàs i Cerc, ribera del Segre, CG7690, 700 m, bosc de ribera pertorbat, 13-VII-2013; la Seu d'Urgell, ribera del Segre vora el Parc del Segre, CG7390, $690 \mathrm{~m}$, bosc de ribera pertorbat, 13-VII-2013.

Arbre originari de l'est dels Estats Units, que a Europa es cultiva com a ornamental i que de vegades es presenta com a subespontani o naturalitzat (exs. Verloove, 2006; Pysek et al., 2012). A Catalunya va ser citat per primera vegada com a subespontani vora Olot (Casasayas, 1989) i més endavant ha estat considerat ja com a parcialment naturalitzat a la Garrotxa (Oliver, 2009). Al tram indicat del Segre s'observen individus espontanis, nascuts a partir de llavors d'exemplars cultivats en camins vora el riu. El nombre d'individus detectat és relativament baix, però sembla que l'espècie es troba en un procés incipient de naturalització local, probablement comparable al de la Garrotxa. Per ara, només hem observat menys de deu individus reproductors a la llera del riu (5 a Alàs i 3 a la Seu), però la quantitat de juvenils és força alta (uns 20 i 40 respectivament). Afegim que també hem vist un individu reproductor, de caràcter netament subespontani (aparegut com a resultat d'un abocament de terres), en un altre indret dels Pirineus: Llavorsí (Pallars Sobirà), vora la carretera C-13 al nord del poble, CH5206, $830 \mathrm{~m}$.

\section{Cerastium tomentosum L.}

Alt Urgell: Montferrer i Castellbò, carretera d'accés a la urbanització Balcó del Pirineu, CG7089, 695 m, talussos de marge de carretera, en llocs força apartats de cases i jardins, 13-VII-2013; Cerdanya: Urús, al sud-oest del poble, DG0588, 1330 m, marge d'una pista forestal, VI-2013; RIPOLLÈs: Toses, carretera de Cas- 
tellar de n'Hug a la Molina, sobre el torrent de la Creueta, DG1683, 1900 m, i DG1684, 1850 m, talussos de carretera, VI i VII 2013.

Aportem informació sobre quatre nous nuclis naturalitzats d'aquesta cariofillàcia, molt cultivada als jardins. En aquest sector dels Pirineus sembla que es comporta bàsicament com a planta viària. Ja hi havia estat indicat per Vigo et al. (2003), concretament al costat berguedà del coll de la Creueta (Castellar de n'Hug, DG1783, 1925 m), molt a prop dels nuclis de Toses, els quals suposem que tenen el mateix origen. Al coll de la Creueta es va constatar que l'espècie va aparèixer cap a l'any 2000, a conseqüència de revegetacions artificials en talussos de la carretera afectats per obres d'ampliació. Una dècada més tard aquesta població es manté bé i fins i tot ha augmentat, però resta estrictament limitada als talussos de la carretera, sense que per ara s'hagi observat en hàbitats naturals (prats o pedrusques) de l'entorn. En canvi, una altra cariofil-làcia al·lòctona que va aparèixer simultàniament en aquests talussos, Gypsophila elegans M. Bieb., ja n'ha desaparegut.

\section{Diospyros lotus L.}

Berguedì: Avià, la Plana, DG0656, 475 m, talús amb vegetació ruderal, X-2013.

A les principals flores de referència del territori, aquest arbre originari de les zones temperades d'Àsia no és citat dels Països Catalans per Bolòs \& Vigo (1996) ni Bolòs et al. (2005), mentre que Castroviejo (1997) esmenta vagament l'existència de citacions antigues a Catalunya i les Balears. A Catalunya aquestes dades antigues són del segle Xıx, de Vidrà (Osona) i Sant Miquel del Fai (Vallès Oriental) i sí que havien estat recopilades a la síntesi sobre flora al-lòctona de Casasayas (1989), qui ja no va retrobar l'espècie. Els darrers anys, però, s'ha detectat la naturalització de D. lotus en diverses localitats valencianes (SENB-CIEF, 2011; http://bdb.cma.gva.es/), on fins fa poc només era citat com a casual (Sanz et al., 2011), i també ha estat citat de manera poc precisa en algun indret del sud de Catalunya. Concretament, és indicat com a subespontani a Cambrils (Sanz \& Sobrino, 2002) i al baix Ebre (Royo, 2006). Amb la dada del Berguedà ampliem a l'interior de Catalunya la informació sobre la seva aparició recent com a planta al-lòctona espontània. A la localitat d'Avià hem observat una desena de peus, amb alçades de 0,3 a $4 \mathrm{~m}$, la major part juvenils no reproductors. Pel que fa al seu origen, el desconeixem; podria ser l'ús de D. lotus com a portaempelts de D. kaki, per ser aquest un dels orígens més freqüents de les poblacions naturalitzades, però el caqui es cultiva molt poc en aquesta zona i no l'hem observat en cap indret pròxim a la població de $D$. lotus.

\section{Euphorbia lathyris L.}

BERguedì: Avià, riera de la Font Calda per sobre del molí del Castell, DG0359, 670 m, herbassars nitròfils en un talús, 22-II-2013; Olvan, riera de la Riba per sobre de Cal Llop, DG0855, 485 m, herbassars higronitròfils, 31-VIII-2013; SoLSONÈs: Guixers, Sant Martí de la Corriu, CG8867, 1170 m, horts abandonats i al peu de murs, 2010-2013.

Aquesta planta no havia estat citada a les dues comarques indicades, i és en general molt rara a la Catalunya central i occidental (BDBC). Els nuclis d'Avià i 
de Guixers deriven clarament de l'antic conreu de l'espècie als mateixos llocs, mentre que el d'Olvan es deu haver originat per transport de llavors per l'aigua des d'algun lloc desconegut situat riera amunt.

Fallopia japonica (Houtt.) Ronse Decr.

CERdanya: Puigcerdà, marge sud-oest del nucli urbà, vessant sobre el polígon industrial la Closa, DG1198, 1180-1190 m, vegetació ruderal en horts abandonats, 2012-2013.

Casasayas (1989) va assenyalar la presència a Puigcerdà d'aquesta espècie, però puntualitzant que hi vivia malament, motiu pel qual la va considerar una subespontània casual. En realitat hi està ben naturalitzada, ja que persisteix un quart de segle més tard i forma una població densa, quasi monoespecífica, que ocupa uns quants centenars de $\mathrm{m}^{2}$. Tot i això, a la Cerdanya no mostra el comportament fortament invasor que caracteritza aquesta planta a gran part d'Europa (Pysek, 2006), perquè no s'ha observat una expansió més enllà d'aquesta zona suburbana. Hem observat també Fallopia japonica cultivada com a ornamental en altres llocs de la Cerdanya, per exemple a Sanavastre (Das) o en altres punts del municipi de Puigcerdà, sense detectar-hi individus escapats.

\section{Galega officinalis L.}

Cerdanya: *Fontanals de Cerdanya, Queixans, ribera del Segre a l'altura de l'estació de Queixans, DG1094, 1090 m, herbassar al costat d'una bassa artificial, 17-IX-2013.

Espècie que aparentment no havia estat indicada a Catalunya des del segle XIX, quan va ser citada de Berga, del baix Montseny i de Ceret (Cadevall, 1919). Els autors moderns han considerat que aquestes citacions corresponen a individus subespontanis, ja que era una planta cultivada com a medicinal (Bolòs \& Vigo, 1984; García Murillo \& Talavera, 1999; Bolòs et al., 2005). G. officinalis ha estat molt dispersada per l'home, fins al punt d'esdevenir fortament invasora en algunes àrees d'Amèrica (http://www.cabi.org), i a la pràctica resulta difícil establir d'on és autòctona. A Europa, sovint s'havia considerat autòctona de moltes regions meridionals, amb extrem occidental d'àrea al nord de la península Ibèrica; però ara el criteri dominant és acceptar que només seria nativa de la Mediterrània oriental. Coherentment amb aquest criteri, ja ha estat incorporada a diverses llistes de plantes invasores de França, i també a la península Ibèrica és considerada introduïda a Galícia i el País Basc (Romero, 2007; Campos \& Herrera, 2009), zones on encara era citada com a autòctona per García Murillo \& Talavera (1999). El nucli trobat a la ribera del Segre formava una taca d'uns $5 \times 2 \mathrm{~m}$, on hi havia una vintena d'individus abundantment fructificats quan es va fer l'observació, de manera que és probable que s'hi estableixi una població viable a mitjà termini. Desconeixem l'origen d'aquestes plantes, que podrien provenir d'exemplars utilitzats en jardineria o d'algun transport a llarga distància per vehicles. D'acord amb la informació coneguda, les localitats modernes més pròximes a la de la Cerdanya se situarien a la conca mitjana del riu Garona i al baix Llenguadoc (http://www. tela-botanica.org). 
Gomphocarpus fruticosus (L.) W.T. Aiton

BERguedÀ: Puig-reig, perifèria nord del nucli urbà, DG0748, 435 m, herbassars ruderals vora la carretera, XII-2012.

Planta d'origen africà força estesa a les zones litorals de Catalunya, però que pràcticament no s'aparta de les zones de clara influència marítima (Bolòs et al., 2001; BDBC). Aparentment, existeix una sola citació relativament interior i és antiga, dels voltants d'Igualada (Salvaña, 1885), recollida a la síntesi de Casasayas (1989). La citació de Puig-reig se situa en una zona molt més interior, en plena Depressió Central. Hi vam observar només dos peus de petita talla, fructificats, que no hem retrobat l'any 2013. Suposem que es tracta d'una presència accidental, efímera, similar a la d'altres espècies termòfiles que rarament persisteixen a l'interior, com també podria ser el cas de Ricinus communis que comentem més endavant.

Juncus tenuis Willd.

Alt Urgell: Ribera d'Urgellet, la Parròquia d'Hortó, cap al Cortal del Sants, CG6487, $1100 \mathrm{~m}$, marges de pista humits, 8-VII-2013.

Nova localitat d'aquest tàxon al-lòcton d'origen nord-americà als Pirineus centrals, on està en expansió. A l'alta vall del Segre ja havia estat assenyalat de la Cerdanya i d'Andorra (Bolòs \& Vigo, 2001; BDBC).

Heracleum mantegazzianum Sommier \& Levier

Cerdanya: Fontanals de Cerdanya, Queixans, ribera del Segre cap al Prat del Comú, DG1094, 1090 m, sotabosc d'una verneda, 2-IX-2103. Fontanals de Cerdanya, ribera del Segre entre Queixans i les Pereres, DG1195, 1100 m, sotabosc d'una verneda, 19-IX-2013.

Noves localitats que confirmen l'establiment d'aquesta espècie invasora d'origen caucàsic a la ribera del Segre, i que se situen entre les dues ja indicades a Aymerich (2013b). En cada nucli, respectivament, hem observat cinc i dotze individus reproductors, a més d'uns quants no reproductors.

\section{Hypericum calycinum L.}

Berguedì: Puig-reig, vessant de la riba dreta del Llobregat, entre les colònies Marçal i Vidal, DG0744, 370 m, bardissa, 17-XI-2013; Vilada, cap al molí del Cavaller, DG1064, 640 m, talús artificial envoltat de bosc de pi roig, 26-IV-2014.

Espècie originària de la Mediterrània oriental, molt utilitzada en jardineria $\mathrm{i}$ que sovint s'escapa; està més o menys naturalitzada, per exemple, a Anglaterra (www.brc.ac.uk/plantatlas/). A Catalunya tan sols en coneixem dues citacions com a planta subespontània, vora carreteres en dues localitats d'Osona, Tavertet i Viladrau (Casasayas, 1989). Al Berguedà coneixíem el cas d'una població extensa i que ara es pot considerar autosostenible en un jardí semiabandonat a la Colònia Prat (Puig-reig, DG0749, 410-420 m), però en aquesta localitat pràcticament no s'ha expandit fora dels límits de l'antiga zona enjardinada (només algunes tiges han arribat fins a menys de $5 \mathrm{~m}$ de la seva perifèria, per creixement vegetatiu). En canvi, els dos nuclis que reportem en aquesta nota es poden consi- 
derar naturalitzats. El nucli de Vilada s'ha generat amb tota probabilitat per l'abocament de deixalles de jardineria i runa, i actualment ocupa una superfície d'uns $15 \mathrm{~m}^{2}$. El nucli de Puig-reig és d'origen desconegut, se situa en un indret apartat 600-700 m de les cases més pròximes i sembla format per una sola taca de l'espècie que ocupa una superfície de poc més d' $1 \mathrm{~m}^{2}$.

Ligustrum ovalifolium Hassk.

Alt URgell: Ribera d'Urgellet, marge esquerre del riu Segre entre el Mas d'Eroles i la Borda del Perillós, CG6886, 630 m, talús embardissat sobre el riu, 20-X-2013.

Hem observat dos individus de mida gran d'aquesta espècie, que tot i estar integrats en la vegetació natural és incert que siguin subespontanis; encara que se situen lluny de cases, pel seu aspecte també podrien haver estat plantats fa temps. En indrets pròxims no hi hem vist cap altre individu, bé que la prospecció ha estat molt limitada. Es tracta d'una planta originària d'Àsia oriental, molt utilitzada en jardineria i que a Catalunya ha estat assenyalada com a rarament subespontània al litoral per Casasayas (1989) i com a persistent de cultiu a la Garrotxa (Oliver, 2009).

Muscari armeniacum Leichtlin ex Baker

Berguedì: Castellar de n'Hug, riba esquerra del Llobregat a la Farga Vella, DG1781, $1200 \mathrm{~m}$, relleixos d'un aflorament de roca, V-2014.

Espècie originària del sud-est d'Europa, Àsia menor i el Caucas que es cultiva com a planta ornamental de jardí i de vegades s'escapa i es naturalitza. És una al-lòctona molt estesa a Anglaterra (www.brc.ac.uk/plantatlas) i també s'ha citat de manera local en altres zones d'Europa occidental com Bèlgica (Verloove, 2006) o el centre de França (http://www.tela-botanica.org), però no sabem que fins ara hagués estat indicada de la península Ibèrica. El seu aspecte és similar al de M. neglectum Guss. ex Ten., amb el qual s'havia confós molt a Anglaterra, però $M$. armeniacum es distingeix per caràcters com les flors d'un blau més clar i subesfèriques (no obovoides), així com també per unes fulles en general més amples i llargues. A la localitat de Castellar de n'Hug el coneixem des de fa una desena d'anys, tot i que fins fa poc no l'havíem identificat. Fa una petita població (un centenar d'individus reproductors, molt agregats) en un aflorament rocós vora el riu, on creix barrejat amb Sedum album, S. montanum, Saxifraga paniculata, Thymus vulgaris subsp. palearensis i Stellaria holostea, entre d'altres espècies. Suposem que aquesta població es devia originar a causa de l'abocament de terres o de restes de jardineria des d'un hotel situat a molt pocs metres, bé que actualment no hem vist $M$. armenicum cultivat als jardins d'aquest hotel.

\section{Physalis peruviana L.}

BERGuedÀ: *Berga, Colònia Rosal, DG0658, 475-480 m, herbassars higronitròfils a la llera de cursos d'aigua, XI-2013.

A Catalunya, les úniques dades publicades d'aquesta espècie sud-americana que coneixem són de fa més d'un segle i van ser recollides per Casasayas (1989), qui no la va retrobar: una citació del segle XIX prop de Barcelona (Costa, 1877) i un plec recol·lectat a Cambrils l'any 1909. Tot i això, sabem d'una observació 
moderna d'un sol exemplar en un marge d'hort del Baix Empordà, a Fonteta, municipi de Forallac (Albert Mallol, com. pers.), i a l'herbari BCN n'hem vist plecs recents procedents d'un parell de localitats del Baix Llobregat (leg. Hilari Álvarez). Els darrers temps el fruit d'aquesta solanàcia s'ha usat força en pastisseria i és cultivada a petita escala en jardins i horts, bé que és més habitual que els fruits siguin d'importació. No és gaire sorprenent, per tant, que n'apareguin exemplars espontanis de manera accidental, a conseqüència d'escapaments de cultiu o de deixalles d'alimentació. A la Colònia Rosal hi vam observar només quatre individus que aparentment no van arribar a fructificar, dos a la llera del Llobregat i dos al tram final de la riera de la Fontcalda, pocs metres abans de l'aiguabarreig amb el riu.

\section{Rhus typhina L.}

Cerdanya: Lles de Cerdanya, vora la cruilla de la carretera de Puigcerdà a la Seu d'Urgell i la carretera d'accés a Lles i Arànser, CG9290, 960 m, marges d'un camp abandonat, 3-X-2013.

Espècie originària de la part oriental d'Amèrica del Nord, que és utilitzada en jardineria i que es presenta com a naturalitzada o subespontània en molts llocs d'Europa, ocasionalment amb caràcter invasor. Tot i que a Catalunya s'observa sovint als jardins, no en sabem de cap dada com a escapada de cultiu. Desconeixem la localització de les poblacions naturalitzades més properes: a França és citada de la major part del territori, incloent els departaments pirinencs (http:// www.tela-botanica.org), però no és clar si les dades tenen en compte també la seva presència com a planta cultivada; d'altra banda, a la península Ibèrica, ha estat citada com a localment naturalitzada a la franja atlàntica (Romero, 2007; Güemes \& Sánchez-Gómez, 2013). A la localitat de la Cerdanya hi hem vist un individu gran aparentment plantat fa temps, al seu costat 2 individus petits ja reproductors que semblen nascuts de manera espontània i 11 juvenils, i a uns 20 m de distància un grup d'una trentena de peus juvenils. Per ara es tracta d'una presència casual, però considerant la quantitat d'individus és probable una naturalització local a mitjà termini. Aparentment la major part d'aquests individus han nascut de llavor, fet poc freqüent a Europa, on el principal mecanisme de dispersió de l'espècie és la reproducció vegetativa.

\section{Ribes rubrum L.}

Cerdanya: *Isòvol, Prades de Segre, DG0593, 1050 m, verneda, 24-IV-2013.

Les dades sobre l'estatus a Catalunya d'aquesta espècie són notablement confuses. Sembla indubtable que es tracta d'una planta al-lòctona, però amb la informació bibliogràfica es fa difícil distingir les indicacions referides a individus cultivats de les d'aquells naturalitzats. En alguns casos fins i tot existeix incertesa sobre la fiabilitat de les dades, que podrien ser degudes a confusions amb l'autòcton $R$. petraeum. En síntesis florístiques modernes és considerat cultivat i possiblement subespontani (Bolòs \& Vigo, 1984), subespontani casual (Casasayas, 1989) o rarament cultivat i subespontani amb dubtes (Bolòs et al., 2005). Blanca (1997) el cita de les províncies de Girona i de Lleida, i considera que a la penín- 
sula Ibèrica és cultivat i naturalitzat esporàdicament, però «potser espontani en algunes localitats de les muntanyes catalanes». La major part de dades referides a aquesta espècie són antigues i ja foren recopilades per Cadevall (1919), on se cita de l'Aran, la Cerdanya i la Garrotxa, sense precisar gaire el seu estatus. Les dades de la Garrotxa sembla que procedien d'exemplars cultivats, o com a molt subespontanis en marges d'algun hort, de manera que Bolòs \& Vigo (1984) no les van considerar, tot i que Oliver (2009) encara la cataloga a la comarca com a allòctona efímera. Les de l'Aran, de Montgarri i l'Artiga de Lin (Llenas, 1912), no sabem que hagin estat confirmades i no seria estrany que corresponguessin a confusions amb $R$. petraeum; si més no, aquesta és l'única espècie que hem vist créixer, abundant, entre les ruïnes de l'antic poble de Montgarri. En la nostra opinió, també semblen assignables a $R$. petraeum dues citacions posteriors al $\mathrm{Pa}$ llars recollides al BDBC (Llensa, 1953). Pel que fa a la Cerdanya, Cadevall (1919) diu explícitament que hi és «cultivat i espontani», però no sabem si ho fa en base a dades pròpies o si interpreta una citació prèvia de Vayreda (1882) a la Molina, que també assenyala i que modernament ha estat considerada com a segurament errònia (Vigo et al., 2003).

La dada que ara aportem del riberal del Segre indica que, almenys a la Cerdanya, $R$. rubrum es presenta com a naturalitzat o com a subespontani molt persistent, ja que s'han observat individus reproductors i de mida gran — que segurament estan presents des de fa molts anys - dins un bosc de ribera allunyat de pobles $\mathrm{i}$ cases. No podem confirmar l'existència de cap veritable població naturalitzada, perquè només hem vist dos individus, però la dificultat de detectar l'espècie dins aquestes vernedes ens fa suposar que el nombre real de plantes deu ser més alt. Afegim que a la Cerdanya també hem vist $R$. rubrum com a resta de cultiu, creixent en una paret dins el poble de Meranges (DG0099, $1530 \mathrm{~m}$ ).

\section{Ricinus communis L.}

BerguedÀ: Avià, Colònia Rosal, DG0658, 475 m, herbassars nitròfils a la riba i a la llera del Llobregat, 28-IX-2013.

Espècie al-lòctona frequient a les comarques litorals i prelitorals de Catalunya, però que gairebé no ha estat citada de l'interior (Bolòs et al., 1999; BDBC). La localitat que aportem és la segona més interior que coneixem, després d'una citació d'Adrall, a l'alt Segre (Casasayas, 1989); en aquesta darrera zona, en l'actualitat (2013) hem observat el ricí cultivat molt a prop, a Arfa, però no naturalitzat. Al Llobregat hi hem observat una quinzena d'individus escampats al llarg de $200 \mathrm{~m}$, i probablement es tracti d'una població efímera.

\section{Salvia sclarea L.}

Alt Urgell: Montferrer i Castellbò, urbanització Balcó del Pirineu, CG7088, $750 \mathrm{~m}$, talussos assolellats i erms enmig de zones residencials, 13-VII-2013.

Nova localitat d'aquesta espècie naturalitzada, que a Catalunya sol fer poblacions temporals i que ha estat molt poc citada a l'àmbit pirinenc (Bolòs et al., 2004; BDBC). 


\section{Silene noctiflora $\mathrm{L}$.}

CERdanya: Bellver de Cerdanya, basses de Gallissà, al marge esquerre del Segre, CG9791, 995 m, herbassars en clarianes del bosc de ribera, 9-IX-2013; Bellver de Cerdanya, riberal del Segre entre els torrents de la Bavosa i de la Fou de Bor, DG0091-0191, 1020-1025 m, herbassars i bardisses en vores de camins, 9-IX2013; Bellver de Cerdanya, al sud de Baltarga, entorn del torrent de la Bavosa, DG0190, $1050 \mathrm{~m}$, herbassars vora camins i clarianes nitrificades, 9-IX-2013; Bolvir, riberals del Segre i del Querol, DG0795-0894-0995 i DG1095, 1070-1095 m, esparsa en clarianes de bosc de ribera, herbassars nitròfils i bardisses, IX i X-2013; Fontanals de Cerdanya, riberal del Segre per damunt del pont de Soler (zona de la devesa del Cornet-prat del Comú), DG0994, 1085 m, herbassars en vores de camins i bardisses, 2-IX-2013; Fontanals de Cerdanya, riba esquerra del Segre per damunt del pont de Queixans, DG1194, 1100 m, herbassar en una clariana del bosc de ribera, 19-IX-2013; Fontanals de Cerdanya, ribera del Segre entre Queixans i les Pereres, DG1195, 1100 m, herbassar nitròfil vora un camí, 19-IX-2013; Ger, riberal del Segre al Molí de Ger, DG0694, 1060 m, vorades del bosc de ribera, 28-X-2013; Lles de Cerdanya, ribera del Segre entre Martinet i els Banys de Músser, CG9190, 940-950 m, talussos i marges de prat de dall, 10-X-2013; Montellà i Martinet, ribera del Segre cap a la Farga, CG9390, 970 m, clarianes del bosc de ribera, 10-X-2013.

Aportem un conjunt de localitats que precisen la distribució local d'aquesta espècie recentment descoberta a la Cerdanya, que per ara és l'única zona de Catalunya i de la península Ibèrica en què es coneix (Aymerich, 2013b). És força més freqüent del que havia semblat inicialment i, considerant l'extensió ara coneguda d'aquesta planta, és improbable que es tracti d'una introducció recent, hipòtesi que en un primer moment havia semblat més versemblant. Actualment es coneix al llarg de tot el recorregut del Segre a la Cerdanya, amb una distància entre localitats extremes d'uns $23 \mathrm{~km}$, i també en algunes localitats una mica apartades del riu. És interessant que a la Cerdanya les poblacions es facin sobretot en clarianes poc humides del bosc de ribera, perquè a la major part d'Europa aquesta planta es comporta sobretot com a mala herba dels camps.

\section{Solanum physalifolium Rusby}

Cerdanya: *Puigcerdà, pla de Rigolisa, a la perifèria nord del nucli urbà, DG1299, $1220 \mathrm{~m}$, hort, 23-IX-2013.

Espècie al-lòctona originària d'Amèrica del sud que, segons les dades disponibles, fins ara no havia estat citada de Catalunya; en l'àmbit dels Països Catalans ha estat indicada de València (Sanz et al., 2011). Està força estesa a Europa des de fa temps (exs. Verloove, 2006; Sobrino \& Sanz, 2011; Pysek et al., 2012), on es presenta com a mala herba dels conreus o com a planta ruderal. La citació que coneixem més pròxima a la Cerdanya és del departament d'Aude, al litoral del Llenguadoc (http://www.tela-botanica.org). A Puigcerdà l'hem vista abundant (unes quantes desenes d'individus) en un hort suburbà. 


\section{Sorbaria tomentosa (Lindl.) Rehder}

Cerdanya: Bolvir, entre el Mas Aravó i el Club de Golf Cerdanya, DG0995, $1090 \mathrm{~m}$, bardissa humida vora una sèquia, 17-VII-2013.

Arbust originari de l'Himàlaia, que es cultiva com a ornamental i que ha estat citat com a subespontani o naturalitzat en diversos països d'Europa (Vivant, 1971; Aizpuru et al., 2000; Verloove, 2006; www.brc.ac.uk/plantatlas/). A Catalunya és indicada com a espècie rarament subespontània per Bolòs et al. (2005), i de manera més concreta a la rodalia de Barcelona per Morales (1999). A la nova localitat de la Cerdanya té per ara també una presència casual, com a escapament de jardí, però no es pot excloure una futura naturalització local, ja que hi hem observat dos individus joves recentment nascuts, al costat de dos adults reproductors.

\section{Ulmus pumila L.}

Alt Urgell: Alàs i Cerc-la Seu d'Urgell, ribera del Segre, CG7390-7490-75907690, 680-700 m, abundant en boscos de ribera pertorbats, arenys fluvials i marges de camins, 13-VII-2013; Ribera d'Urgellet, Camí Ral entre Arfa i la Seu d'Urgell, CG7087, 650 m, marges viaris i —més rar-a la llera del riu Segre, 13-VII-2013.

L'om siberià, originari del centre i nord-est d' Àsia, ha estat molt cultivat com a arbre ornamental en les darreres dècades, sobretot per la seva resistència a la grafiosi, malaltia que ha afectat fortament l'autòcton Ulmus minor, amb el qual es pot hibridar U. pumila (Cogolludo-Agustín et al., 2000; Brunet et al., 2013). Ha esdevingut una espècie invasora important a Amèrica del Nord (Wieseler, 2005), mentre que a Europa és poc citat com a planta al-lòctona naturalitzada. A Catalunya va ser indicat com a subespontani per primera vegada en zones urbanes de Barcelona (Casasayas, 1989). Més endavant ha anat apareixent en ambients suburbans o viaris de molts altres llocs, en forma d'individus subespontanis o de petits nuclis naturalitzats, però aquesta implantació al territori ha estat molt poc reflectida a la bibliografia botànica i, d'altra banda, sovint ha estat inadvertida perquè s'ha confós amb U. minor. La implantació de l'espècie a la ribera del Segre vora la Seu d'Urgell resulta excepcional a Catalunya, per l'extensió ocupada (té una presència forta al llarg de més de $4 \mathrm{~km}$ de riu) i per la gran quantitat d'individus observats (milers, si es compten tant els adults com els juvenils). Aquesta abundància local s'explica perquè es tracta d'un tram fluvial desnaturalitzat i perquè $U$. pumila ha estat molt plantat a les vores dels camins que ressegueixen el riu en tots dos costats. Aquest tram del Segre va ser molt afectat per les riuades de 1982, després va ser canalitzat, eliminant-ne el bosc de ribera, i poc després els terrenys adjacents al riu es van enjardinar com a part de les actuacions relacionades amb el Parc Olímpic del Segre de 1992; en conjunt, aquesta «suburbanització» del riu va afavorir l'aparició d'arbres exòtics com U. pumila. Tot i la implantació d'aquesta espècie al tram pertorbat del riu, cal precisar que pràcticament desapareix aigües avall del Parc del Segre, on s'ha mantingut un bosc de ribera més o menys ben conservat, cosa que posa de manifest les limitacions d'aquest om per comportar-se com una veritable espècie invasora. Al tram entre la Seu i Arfa ja gairebé només s'observen individus subespontanis vora els camins, nascuts a par- 
tir d'exemplars plantats com a arbres viaris, és a dir, que hi segueix el patró habitual al país. La naturalització local d'U. pumila és probable també en altres indrets de l'alt Segre, ja que l'hem observat plantat en altres llocs, com per exemple als marges de la carretera de la Seu i Puigcerdà vora Martinet i el Pont de Bar.

\section{Vitis labrusca L.}

Alt Urgell: Josa i Tuixén, marge dret del riu de Josa, al nord-est del poble de Tuixén, CG8176, 1140 m, bardissa en un marge de prat, VI-2013; Josa i Tuixén, sota Cal Patraco, CG7977, 1070 m, bardisses, VI-2013 (P. Aymerich, herb. pers,).

Referim, amb certa cautela, a aquesta espècie americana dos nuclis naturalitzats de vinya en bardisses de Tuixén, en què semblen ben establertes i ocupen superfícies d'algunes desenes de $\mathrm{m}^{2}$. Com passa amb la major part de vinyes americanes introduïdes a Europa, l'assignació segura a V. labrusca resulta complicada, a causa de la possible hibridació amb $V$. vinifera i de les limitacions de les descripcions disponibles a la bibliografia, però creiem que les plantes de Tuixén són atribuibles a aquest tàxon, si més no en el sentit que se li sol donar a les flores europees. Les principals característiques que fan referibles aquestes plantes a $V$. labrusca són l'indument molt dens grisenc-blanquinós del revers foliar (persistent, però especialment visible a les fulles joves) i la presència de circells o flors en quasi tots els nusos de les ramificacions terminals (Laguna, 2003; Everhart, 2010). V. labrusca gairebé no ha estat indicada de Catalunya com a planta naturalitzada o subespontània, a diferència d'altres països europeus. Fa poc la vam indicar d'una localitat no gaire allunyada de l'alt Solsonès (Aymerich, 2013a), on tenia un caràcter molt menys naturalitzat.

\section{Vitis rupestris Scheele}

Alt Urgell: Arsèguel, solells al nord del Segre, entre la Quera i el Pont d'Arsèguel, CG8290, 790 m, marges de camps abandonats i de prats, 2013; Cava, sota Ansovell, CG8387, 1150-1250 m, marges embardissats d'antics camps, 2013; Estamariu, cap a la Quera, solells al nord del Segre, CG8090, 800 m, antigues feixes amb vegetació arbustiva, 2012-2013; Montferrer i Castellbò, al sud d'Aravell, CG6890, 720 m, marges de camps i prats, X-2013; el Pont de Bar, solells entre els Banys de Sant Vicenç i el Pont de Bar, CG8491-8492-8592, 850-950 m, marges de camps, antigues feixes abandonades i comunitats arbustives pròximes, 2013; el Pont de Bar, solells al nord del Segre, a l'alçada dels Arenys, CG8891, 915 m, feixes abandonades, 2012-2013. CERDANyA: Lles de Cerdanya, riberal del Segre cap a l'estret de Mollet, CG8991, 930 m, vorades de bosc i bardisses en antics camps, 2013.

Segons les dades disponibles, aquesta és l'espècie americana de vinya que té una àrea més extensa com a planta naturalitzada a les zones mediterrànies dels Països Catalans, on es mantindria bàsicament per multiplicació vegetativa (Laguna, 2003; Aymerich, 2013a). En canvi, a l'alt Segre, l'espècie més habitual és $V$. riparia (Aymerich, 2013b). En aquesta zona, V. rupestris també és present, però sembla concentrada bàsicament als vessants solells més càlids del Baridà, entre la Seu d'Urgell i Martinet. És comuna sobretot a les feixes abandonades 
sobre el Pont de Bar, i en alguns llocs s'ha estès fins a matollars i boscos clars pròxims, en terrenys que aparentment no havien estat cultivats; puntualment hi hem vist créixer juntes, en pocs metres, aquesta espècie, $V$. riparia i $V$. vinifera.

\section{Discussió}

En aquesta nota aportem citacions d'un total de 84 tàxons, 57 dels quals autòctons de Catalunya i 27 d'al-lòctons. Cal precisar que és molt probable que algunes plantes autòctones de Catalunya siguin introduïdes a l'àmbit d'estudi (cas de Berberis vulgaris subsp. seroi i Fraxinus angustifolia subsp. oxycarpa) i que altres (Silene muscipula, Solanum villosum o Glaucium corniculatum) potser només hi tenen una presència accidental. Pel que fa a les plantes al-lòctones, el seu grau de naturalització local és molt divers, però dominen les que no han aconseguit establir poblacions consolidades i per ara s'han de considerar casuals.

Segons la informació de referència disponible, aquestes citacions inclouen diverses novetats per a la flora dels Països Catalans o de Catalunya. És nova per a la flora dels Països Catalans una espècie que considerem autòctona, Persicaria minor, i cinc espècies al-lòctones que per ara presenten un grau de naturalització incipient (Rhus typhina, probablement també Muscari armeniacum i Bunias orientalis) o bé només estan representades per individus anecdòtics (Acer saccharinum i Aubrieta columnae). Una cinquena espècie, Solanum physalifolium, és nova per a Catalunya, però ja havia estat indicada del País Valencià. Aparentment tampoc havia estat citat l'híbrid Salix x abnormis, el qual s'ha vist que a la serra del Cadí arriba a constituir una petita població autònoma. I, en certa manera, també es podrien considerar novetats florístiques Galega officinalis i Ribes rubrum, perquè presentem per primera vegada dades segures d'individus naturalitzats a Catalunya, mentre que les informacions prèvies eren força confuses i incertes, en uns casos pel que fa a la seva fiabilitat $i$ en altres perquè no era gaire clar si es referien a plantes cultivades o espontànies. Un cas particular de novetat és el de les Arabis alpina procedents de cultiu i amb caràcters referibles al que s'ha anomenat subsp. caucasica, que per ara no podem dir si representa la introducció d'un nou tàxon o bé només de gens al·lòctons.

A banda d'aquestes novetats florístiques, també aportem algunes citacions d'espècies que són molt rares a Catalunya. Destaquen les de quatre tàxons que actualment estan llistats com a amenaçats (Sáez et al., 2010) i que disposen de protecció legal (Decret 172/2008, de creació del Catàleg de flora amenaçada de Catalunya): Daphne alpina, Epipogium aphyllum, Equisetum fluviatile i Berberis vulgaris subsp. seroi. En relació amb la flora amenaçada, cal dir que Persicaria minor, citada més amunt com a novetat, hauria de ser incorporada a la Llista Vermella de flora de Catalunya; amb la informació que ara tenim i aplicant els criteris de la IUCN (2001), sembla que qualificaria com a CR B2ac(ii,iv), és a dir, «en perill crític» per tenir una sola població i experimentar fluctuacions extremes en l'àrea d'ocupació i el nombre d'individus madurs, fluctuacions que derivarien de l'ús agroramader del lloc on viu. Altres espècies autòctones no estan catalogades com a amenaçades però han estat molt poc citades a la Catalunya autònoma, com és el cas de Sisymbrium 
macroloma, Spergularia segetalis, Saxifraga retusa o Veronica dillenii, bé que les dues darreres estan més documentades en zones pròximes dins l'àmbit administratiu d'Andorra o de la Catalunya Nord. Entre les al-lòctones, compten amb molt poques citacions Achillea filipendulina, Berberis aquifolium, Diospyros lotus, Hypericum calycinum, Physalis peruviana o Sorbaria tomentosa.

Pel que fa a citacions d'interès més regional o local, algunes de les dades aportades posen de manifest el coneixement florístic encara deficient de la plana de la Cerdanya i de l'ampli sector dels Pirineus axials entre els rius Valira i Querol (el que al text hem anomenat sector Tosa Plana-Puigpedrós), tot i tractar-se de zones freqüentades per botànics des de fa més d'un segle. En el cas de la plana cerdana sorprèn que, aparentment, es retrobin plantes de les quals no coneixem citacions publicades des del segle XIX o primers del xx (Ribes rubrum, Spergula morisonii, Trifolium retusum), que altres relativament freqüents gairebé no estiguessin documentades amb citacions precises (Trifolium hybridum, Persicaria hydopiper) o que no s'hagi detectat fins fa molt poc Silene noctiflora, que es pot considerar comuna al riberal del Segre. Aquestes mancances suggereixen que en temps moderns les parts baixes de la Cerdanya han estat objecte de poca prospecció florística, o bé que aquesta s'ha limitat a pocs ambients o sectors. Al sector axial Tosa Plana-Puigpedrós, el descobriment de noves localitats de plantes molt aparents (Xatardia scabra, Papaver lapeyrousianum o Viola diversifolia), la confirmació de la presència dins la part corresponent a la Catalunya administrativa d'altres (Saxifraga retusa, Artemisia eriantha, Gnaphalium norvegicum, Potentilla frigida) o sorpreses com trobar als vessants inferiors una planta tan termòfila com Mercurialis huetii, semblen atribuibles a un clar dèficit de prospecció a la part situada dins la Catalunya autònoma (poc visitada fora dels entorns dels estanys de la Pera i de Malniu-Puigpedrós), en contrast amb el coneixement més precís que es té de la flora a les parts d'aquest sector pirinenc situades dins zones d'administració andorrana o francesa.

\section{Referències bibliogràfiques}

Aizpuru, I.; Aseginolaza, C.; Uribe-Echebarría, P.M.; Urrutia, P.; Zorrakin, I. 2000. Claves ilustradas de la flora del País Vasco y territorios limítrofes. Eusko Jaurlaritzaren Argitalpen Zerbitzu Nagusia. Vitoria-Gasteiz.

Álvarez de la Campa, J. 2004. Vegetació del massís del Port. Col·lecció Pius Font i Quer. Institut d'Estudis Ilerdencs. Lleida.

Amigó, J.J. 2001. Aspectes remarcables de la flora i la vegetació de la Cerdanya. Muntanya 836: $143-152$.

Aymerich, P. 1998. Aportació al coneixement florístic del nord de Catalunya. Butlletí Institució Catalana Història Natural 66: 41-57.

Aymerich, P. 2003. Notes florístiques de les conques altes dels rius Segre i Llobregat. Acta Botanica Barcinonensia 48: 15-28.

Aymerich, P. 2013a. Contribució al coneixement florístic del territori ausosegàrric (NE de la península Ibèrica). Orsis 27: 209-259.

Aymerich, P. 2013b. Sobre algunes espècies al·lòctones a l'alt Segre, noves o molt rares per a la flora catalana. Orsis 27: 195-207. 
Aymerich, P. 2013c. Notes sobre algunes plantes rares o amenaçades als Pirineus catalans. Butlletí Institució Catalana Història Natural 77: 5-26.

Aymerich, P. 2013d. Plantas alóctonas de origen ornamental en la cuenca alta del río Llobregat (Cataluña, noreste de la Península Ibérica). Bouteloua 16: 52-79.

Aymerich, P.; Soriano, I.; Llistosella, J. 2008. Addicions a la flora vascular del Parc Natural del Cadí-Moixeró i de les serres veïnes (Prepirineus orientals ibèrics). Acta Botanica Barcinonensia 51: 35-47.

Aymerich, P.; Tenas, B.; Vigo, J. 2012. Notes florístiques del Ripollès (Pirineus orientals). Acta Botanica Barcinonensia 53:11-26.

Ballesteros, E. 1989. Contribució al coneixement florístic de l'Alta Ribagorça i la Vall d'Aran. Butlletí Institució Catalana Història Natural 57: 79-85.

Baranda, J. 1984. Georges Rouy (1851-1924). Su obra botánica en España. Ruizia 1. Monografías del Real Jardín Botánico. Madrid.

Batarda, R. 1992. Nota sobre Aubrieta deltoidea (L.) DC. (Cruciferae). Anales Jardín Botánico Madrid 50(1): 144.

Benito Ayuso, J.; Arizaleta, J.A.; Medano, L.M. 2003. Epipogium aphyllum Sw. In: Bañares, A.; Blanca, G.; Güemes, J.; Moreno, J.C.; Ortiz, S. (Eds.). Atlas y Libro Rojo de la flora vascular amenazada de España: 238-239. Dirección General de Conservación de la Naturaleza. Madrid.

Blanca, G. 1997. Ribes L. In: Castroviejo, S; Aedo, C.; Laínz, M.; Morales, R.; Muñoz Garmendia, F.; Nieto Feliner, G.; Paiva, J. (Eds.). Flora iberica. Vol. V. EbenaceaeSaxifragaceae: 86-94. Real Jardín Botánico de Madrid. CSIC. Madrid.

Blanco, P. 1993. Salix L. In: Castroviejo, S.; Aedo, C.; Cirujano, S.; Laínz, M.; Montserrat, P.; Morales, R.; Muñoz Garmendia, F.; Navarro, C.; Paiva, J.; Soriano, C. (Eds.). Flora iberica. Vol. III. Plumbaginaceae (partim)-Capparaceae: 477-517. Real Jardín Botánico de Madrid. CSIC. Madrid.

Bolòs, O. 1998. Atlas corològic de la flora vascular dels Països Catalans. Primera compilació general. ORCA: Volum extraordinari. Institut d'Estudis Catalans. Secció Ciències Biològiques. Barcelona.

Bolòs, O.; Font, X.; Pons, X.; Vigo, J. (Eds.). 1997. ORCA. Atlas corològic de la flora dels Països Catalans 7. Institut d'Estudis Catalans (Sec. Ciències Biològiques). Barcelona.

Bolòs, O.; Font, X.; Pons, X.; Vigo, J. (Eds.). 1998. ORCA. Atlas corològic de la flora dels Països Catalans 8. Institut d'Estudis Catalans (Sec. Ciències Biològiques). Barcelona.

Bolòs, O.; Font, X.; Vigo, J. (Eds.). 1999. ORCA. Atlas corològic de la flora dels Països Catalans 9. Institut d'Estudis Catalans (Sec. Ciències Biològiques). Barcelona.

Bolòs, O.; Font, X.; Vigo, J. (Eds.). 2000. ORCA. Atlas corològic de la flora dels Països Catalans 10. Institut d'Estudis Catalans (Sec. Ciències Biològiques). Barcelona.

Bolòs, O.; Font, X.; Vigo, J. (Eds.). 2001. ORCA. Atlas corològic de la flora dels Països Catalans 11. Institut d'Estudis Catalans (Sec. Ciències Biològiques). Barcelona.

Bolòs, O.; Font, X.; Vigo, J. (Eds.). 2003. ORCA. Atlas corològic de la flora dels Països Catalans 12. Institut d'Estudis Catalans (Sec. Ciències Biològiques). Barcelona.

Bolòs, O.; Font, X.; Vigo, J. (Eds.). 2004. ORCA. Atlas corològic de la flora dels Països Catalans 13. Institut d'Estudis Catalans (Sec. Ciències Biològiques). Barcelona.

Bolòs, O.; Montserrat, J.M.; Romo, A.M. 1988. Comunitats vegetals higronitròfiles de la Catalunya pirinenca i de les terres properes. Acta Botanica Barcinonensia 37: 33-34.

Bolòs, O.; Vigo, J. 1984. Flora dels Països Catalans. Vol. 1. Ed. Barcino. Barcelona.

Bolòs, O.; Vigo, J. 1990. Flora dels Països Catalans. Vol. 2. Ed. Barcino. Barcelona.

Bolòs, O.; Vigo, J. 1996. Flora dels Països Catalans. Vol. 3. Ed. Barcino. Barcelona.

Bolòs, O.; Vigo, J. 2001. Flora dels Països Catalans. Vol. 4. Ed. Barcino. Barcelona. 
Bolòs, O.; Vigo, J.; Masalles, R.M; Ninot, J.M. 2005. Flora Manual dels Països Catalans. Ed. 3. Edicions 62. Barcelona.

Braun-Blanquet, J.; Bolòs, O. 1957. Les groupements végétaux du bassin moyen de l'Ebre et leur dynamisme. Anales Estación Experimental Aula Dei 5(1-4): 1-266.

Brunet, J.; Zapata, J.E.; Pecori, F.; Santini, A. 2013. Hybridization and introgression between the exotic Siberian elm, Ulmus pumila, and the native Field elm, U. minor, in Italy. Biological Invasions. DOI: 10.1007/s10530-013-0486-z.

Cadevall, J. 1919. Flora de Catalunya. Vol. 2. Barcelona, Institut de Ciències.

Cadevall, J.; Font Quer, P. 1932. Flora de Catalunya. Vol. 4. Barcelona, Institut de Ciències. Cadevall, J.; Font Quer, P. 1933. Flora de Catalunya. Vol. 5. Barcelona, Institut de Ciències. Cadevall, J. 1937. Flora de Catalunya. Vol. 6. Barcelona, Institut de Ciències.

Campos, J.A.; Herrera, M. 2009. Diagnosis de la flora alóctona invasora de la CAPV. Departamento de Medio Ambiente y Ordenación del Territorio. Gobierno Vasco. Bilbo. 296 p.

Carreras, J. 1993. Flora i vegetació de Sant Joan de l'Erm i de la vall de Santa Magadalena. Col-lecció Estudis 3. Institut d'Estudis Ilerdencs. Lleida.

Carrillo, E.; Mercadé, A.; Ninot, J.M.; Carreras, J.; Ferré, A.; Font, X. 2008. Check-list i Llista vermella de la flora d'Andorra. CENMA-Institut d'Estudis Andorrans-Departament de Medi Ambient d'Andorra.

Casasayas, T. 1989. La flora al-lòctona de Catalunya. Tesi doctoral. Facultat de Biologia, Universitat de Barcelona.

Casellas, J. 1962. El género Medicago L. en España. Collectanea Botanica (Barcelona) 6: 183-291.

Castroviejo, S. 1997. Diospyros L. In: Castroviejo, S.; Aedo, C.; Laínz, M.; Morales, R.; Muñoz Garmendia, F.; Nieto Feliner, G.; Paiva, J. (Eds.). Flora iberica. Vol. V. Ebenaceae-Saxifragaceae: 3-5. Real Jardín Botánico de Madrid. CSIC. Madrid.

Cogolludo-Agustín, M.A.; Agúndez, D.; Gil, L. 2000. Identification of native and hybrid elms in Spain using isozyme gene markers. Heredity 85(2): 157-166.

Costa, A.C. 1877. Suplemento al Catálogo razonado de plantas fanerógamas de Cataluña. Imprenta Barcelonesa. Barcelona.

Cullen, J.; Knees, S.G.; Cubey, H.S. (Eds.). 2011. The European Garden Flora. Vol. 2: Casuarinaceae to Cruciferae. 2nd edition. Cambridge University Press.

Devis, J. 2006. Flora i vegetació del territori comprès entre el riu Segre i el Port del Comte (Prepirineus catalans, Lleida). Tesi doctoral. Universitat de Barcelona.

Everhart, S.E. 2010. Upper canopy collection and identification of grapevines (Vitis) from selected forests in the Southeastern United States. Castanea 75(1): 141-149.

Font, X.; Vigo, J. (Eds.). 2008. ORCA. Atlas corològic de la flora dels Països Catalans 15. Institut d'Estudis Catalans (Sec. Ciències Biològiques). Barcelona.

Galicia, D.; Humbert, S.; Moreno, L.; Moreno, J.C.; Sainz, H. 2002. Mapa 0886: Androsace halleri - Mapa 0889: Androsace laggeri. In: Fernández Casas, F.J.; Fernández Sánchez, A.J. (Eds.). Asientos para un atlas corológico de la flora occidental, 25. Cavanillesia Altera 2: 523-525 i 527-532.

Gamisans, J.; Grüber, M. 1988. Els boscos de pinassa (Pinus nigra subsp. salzmannii) als Pirineus catalans i est-aragonesos: estudi fitosociològic. Monogr. Inst. Pir. Ecol. (Hom. P. Montserrat) 4: 543-552.

García Murillo, P.; Talavera, S. 1999. Galega L. In: S. Talavera, S.; Castroviejo, S.; Aedo, C.; Castroviejo, S.; Romero Zarco, C.; Sáez, L.; Salgueiro, F.J.; Velayos, M. (Eds.). Flora iberica. Vol. VII(I). Leguminosae (partim): 267-273. Real Jardín Botánico de Madrid. CSIC. Madrid. 
Gómez, D. 2013. Atlas de la flora de Aragón: Bunias orientalis. http://proyectos.ipe.csic. es/floragon (Consulta: 26-V-2014)

Gruber, M. 1977. Contribution à la flore des Pyrénées ariègeoises et catalanes : 2e note. Bulletin Societé Botanique de France 124 : 93-194.

Gruber, M. 1978. La végétation des Pyrénées ariégeoises et catalanes occidentales. Tesi doctoral. Université Aix-Marseille III.

Güemes, J.; Sánchez Gómez, P. 2013. Rhus L. In : Castroviejo, S. \& al. (Eds.). Flora iberica. Vol. IX, http://www.rjb.csic.es/floraiberica/ (Consulta: 4-X-2013)

Hourcq, J.J. 2007. Epipogium aphyllum (Swartz) dans les Pyrénées Atlantiques et répartition sommaire des stations connues sur les deux versants des Pyrénées. Isatis 7: 57-63.

IUCN. 2001. IUCN Red List Categories and Criteria: Version 3.1. IUCN Species Survival Commission. IUCN. Gland \& Cambridge.

Karl, R.; Kiefer, C.; Ansell, S.W.; Koch, M.A. 2012. Systematics and evolution of arcticalpine Arabis alpina (Brassicaceae) and its closest relatives in the Eastern Mediterranean. American Journal of Botany 99(4): 778-794.

Koch, M.A.; Kiefer, C.; Ehrich, D.; J. Vogel, J.; Brochmann, C.; Mummenhoffs, K. 2006. Three times out of Asia minor: the phylogeography of Arabis alpina L. (Brassicaceae). Molecular Ecology. 15: 825-839.

Kress, A. 1997. Androsace L. In: Castroviejo, S.; Aedo, C.; Laínz, M.; Morales, R.; Muñoz Garmendia, F.; Nieto Feliner, G.; Paiva, J. (Eds.). Flora iberica. Vol. V. EbenaceaeSaxifragaceae: 22-40. Real Jardín Botánico de Madrid. CSIC. Madrid.

Laguna, E. 2003. Sobre las formas naturalizadas de Vitis L. (Vitaceae) en la Comunidad Valenciana, I. Especies. Flora Montibérica 23: 46-82.

Lazare, J.J.; Cantenot, Y.; Darquistade, A.; Dartiguelongue, S.; Pujos, J.; Riba, S. 2009. Inventaire et étude écologiques des zones humides de la Principauté d'Andorre (programme national 2002-2006): interpretation géosymphytosociologique. Acta Botanica Gallica 156(4): 589-605.

Lewin, J.M. 1998. Atlas préliminaire des orchidées des Pyrénées-Orientales 1993-1997. Naturalia Ruscinonensia 8: 1-109.

Llenas, M. 1912. Contribución al estudio de la flora del Pirineo Central (Valle de Aran). Memòries de la Institució Catalana d'Història Natural. Tom 1, mem. 1.

Llensa, S. 1953. Hallazgos botánicos e impresiones forestales correspondientes a nuestras excursiones por el Pirineo leridano (años 1951 y 1952). Anales Escuela Peritos Agr. Super. Agric. 12: 69-107.

López-Udias, S. 2013. Atlas de la flora de Aragón: Mercurialis huetii. http://proyectos.ipe. csic.es/floragon (Consulta: 26-VII-2013)

Masclans, F.; Batalla, A. 1972. Flora de los montes de Prades. (Continuación). Collectanea Botanica (Barcelona). 8: 139-276.

Mercadal, N. 2013. Atlas de la flora de Aragón: Salix elaeagnos, Salix pyrenaica. http:// proyectos.ipe.csic.es/floragon (Consulta: 16-VIII-2013)

Molero, J. 1982. Noves aportacions a la Flora del Priorat i dels seus entorns. Folia Botanica Miscellanea 3: 11-16.

Molero, J. 1984. Contribució al coneixement fitocenològic dels Catalànids Centrals (Serra de Prades i Montsant): comunitats noves o poc conegudes. Butlletí Institució Catalana Història Natural 51: 139-160.

Morales, R. 1999. Sorbaria (Lindl.) Rehder. In: Muñoz Garmendia; F.; Navarro, C. (Eds.). Flora iberica. Vol. VI. Rosaceae: 12-13. Real Jardín Botánico de Madrid. CSIC. Madrid.

Ninot, J.M.; Batriu, E.; Mercadé, A.; Pérez-Haase, A.; Carrillo, E.; March, S.; Salvat, A. 
2010. Flora vascular de les Planes de Son i la mata de València. In: Germain, A. (Coord.). Els sistemes naturals de les Planes de Son i la mata de València. Treballs Institució Catalana Història Natural 16: 255-325.

Nuet, J. 1998. Noves localitats de Xatardia scabra (Lapeyr.) Meissn. als Pirineus axials catalans. Butlletí Institució Catalana Història Natural 66: 87.

Oliver, X. 2009. Catàleg de la flora vascular al-lòctona de la Garrotxa. Delegació de la Garrotxa de la Inst. Catalana Hist. Nat. 4a edició.

Pascual, R. 2007. Flora de la serra del Montsant (2 vols.). Ed. Rafael Dalmau.

Pedrol, J.; Yera, J.; Ascaso, J. 2002. De plantis vascularibus praesertim ibericis (IV). Munibe 53: 147-156.

Pontacq, J.; Nuet, J. 1999. Epipogium aphyllum al Pallars Sobirà. Muntanya 822: 74.

Pysek, P. 2006. Fallopia japonica. DAISIE (Delivering Alien Invasive Species for Europe). http://www.europe-aliens.org (Consulta: 26-VII-2013)

Pysek, P.; Danihelka, J.; Sádlo, J. et al. 2012. Catalogue of alien plants of the Czech Republic (2nd edition): checklist update, taxonomic diversity and invasion patterns. Preslia 84: 155-255.

Romero, C. 2009. Medicago L. In: Blanca, G.; Cabezudo, B.; Cueto, M; Fernández López, C.; Morales Torres, C. (Eds.). Flora vascular de Andalucía oriental. Vol. 2: 417-427. Consejería de Medio Ambiente. Junta de Andalucía.

Romero, M.I. 2007. Flora exótica de Galicia (noroeste ibérico). Botanica Complutensis 31: 113-125.

Romo, A.M. 1988 Los bosques de Ulmus glabra en los Pirineos centrales catalanes. Lazaroa 10: $89-94$.

Rosell, A. 1978. Flora i vegetació de la Clusa. Tesi de llicenciatura. Universitat de Barcelona.

Royo, F. 2006. Flora i vegetació de les planes i serres litorals compreses entre el riu Ebre i la serra d'Irta. Tesi doctoral. Universitat de Barcelona.

Sáez, L. 1997. Atlas pteridològic de Catalunya i Andorra. Acta Botanica Barcinonensia 44: 39-167.

Sáez, L.; Aymerich, P.; Blanché, C. 2010. Llibre Vermell de les plantes vasculars endèmiques i amenaçades de Catalunya. Argania Editio. Barcelona.

Sáez, L.; Devis, J.; Soriano, I. 2004. Flora vascular de la vall d'Alinyà. In: Germain, J. (Ed.). Els sistemes naturals de la vall d'Alinyà. Treballs de la Institució Catalana d'Història Natural 14: 237-300.

Sales, F.; Hedge, I.C. 2000. Medicago L. In: Talavera, S.; Aedo, C.; Castroviejo, S.; Herrero, A.; Romero Zarco, C.; Salgueiro, F.J.; Velayos, M. (Eds.). Flora iberica Vol. VII (II). Leguminosae (partim): 741-775. Real Jardín Botánico, CSIC. Madrid.

Salvaña, J.M. 1885. Recuerdos botánicos de Igualada. Flora aqualatense póstuma de D. José Bausili y Salamanca. Memoria leída en sesión celebrada el día 30 de junio de 1885. Real Academia Ciencias y Artes. Tomo 2.

Sanz, M.; Dana, E.D.; Sobrino, E. 2004. Atlas de las Plantas Alóctonas Invasoras en España. Dirección General para la Biodiversidad. Madrid. 378 pp.

Sanz, M.; Guillot, D.; Deltoro, V. 2011. La flora alóctona de la Comunidad Valenciana (España). Botanica Complutensis 35: 97-130.

Sanz, M.; Sobrino, E. 2002. Plantes vasculars del quadrat UTM 31T CF34. Cambrils. ORCA: Catàlegs florístics locals 13. Secció Ciències Biològiques. Institut d'Estudis Catalans.

SCOP Sagne. 2007. Inventaire des zones tourbeuses des Pyrénées-Orientales 2002-2006. Rapport technique. 
Sebastià, M.T. 1983. Observaciones sobre la estructura y la ecología de los hayedos del valle de Gresolet (Alt Berguedà). Tesi de llicenciatura. Universitat de Barcelona.

SENB-CIEF. 2011. Identificación de la especie arbórea invasora Diospyros lotus. Full informatiu. Servei d'Espais Naturals i Biodiversitat. Conselleria d'Infraestructures, Territori i Medi Ambient. Generalitat Valenciana. València.

Sobrino, E.; Sanz, M. 2011. Solanum L. In: Talavera, S.; Andrés, C.; Arista, M.; Fernández Piedra, M.P.; Gallego, M.J.; Ortiz, P.L.; Romero, C.; Salgueiro, F.J.; Silvestre, S.; Quintanar, A. (Eds.). Flora iberica. Vol. XI. Gentianaceae-Boraginaceae: 166-195. Real Jardín Botánico de Madrid. CSIC. Madrid.

Soriano, I. 1984. Les valls del Bastareny (alt Berguedà). Flora i paisatge vegetal. Tesi de llicenciatura. Universitat de Barcelona.

Soriano, I. 1992. Estudi florístic i geobotànic de la serra de Moixeró i el massís de la Tosa d'Alp (Pirineus orientals). Tesi doctoral. Universitat de Barcelona.

Soriano, I. 1993. Aportació al coneixement florístic de la serra de Moixeró i el massís de la Tosa d'Alp (Pirineus catalans). Folia Botanica Miscellanea 9: 27-34.

Suárez-Santiago, V.N.; Blanca, G. 2013. Muscari L. In: Rico, E.; Crespo, M.B.; Quintanar, A.; Herrero, A.; Aedo, C. (Eds.). Flora iberica. Vol. XX. Liliaceae-Agavaceae: 171-184.

Suárez-Santiago, V.N.; Salinas, M.J.; Romero, A.T.; Garrido, M.A.; Herrán, R.; RuizRejón, C.; Ruiz-Rejón, M.; Blanca, G. 2007. Polyploidy, the major speciation mechanism in Muscari subgenus Botryanthus in the Iberian Peninsula. Taxon 56(4): 1171-1184.

Talavera, S. 1993. Arabis L. In: Castroviejo, S.; Aedo, C.; Gómez Campo, C.; Laínz, M.; Montserrat, P.; Morales, R.; Muñoz Garmendia, F.; Nieto Feliner, G.; Rico, E.; Talavera, S.; Villar, L. (Eds.). Flora iberica. Vol. IV. Cruciferae-Monotropaceae: 135-163. Real Jardín Botánico de Madrid. CSIC. Madrid.

Vayreda, E. 1882. Nuevos apuntes para la flora catalana. Anales Sociedad Española Historia Natural 11: 41-151.

Verloove, F. 2006. Catalogue of neophytes in Belgium (1800-2005). Scripta Botanica Belgica 39: 1-89.

Vigo, J. 1983. Flora de la vall de Ribes. I. Generalitats. Catàleg florístic. Acta Botanica Barcinonensia 35: 1-793.

Vigo, J.; Soriano, I.; Carreras, J.; Aymerich, P.; Carrillo, E.; Font, X.; Masalles, R.M.; Ninot, J.M. 2003. Flora del Parc Natural del Cadí-Moixeró i de les serres veïnes. Monografies del Museu de Ciències Naturals-Institut Botànic de Barcelona.

Vila, J. 2010. Epipogium aphyllum al Montseny. Acta Botanica Barcinonensia 52: 125127.

Villar, L. 1987. Nota corológica, nomenclatural y taxonómica sobre el género Polygonum L. en la Península Ibérica. Anales Jardín Botánico Madrid 44(1): 180-186.

Villar, L. 1990. Polygonum L. In: Castroviejo, S.; Laínz, M.; López González, G.; Montserrat, P.; Muñoz Garmendia, F.; Paiva J.; Villar, L. (Eds.). Flora iberica. Vol. II. Platanaceae-Plumbaginaceae (partim): 571-586. Real Jardín Botánico de Madrid. CSIC. Madrid.

Villar, L.; Montserrat, P. 2000. Sobre algunas plantas poco conocidas, tanto espontáneas como cultivadas, del Pirineo aragonés. Actas del Congreso de Botánica en homenaje a Francisco Loscos: 763-776. Instituto de Estudios Turolenses. Terol.

Villar, L.; Sesé, J.A.; Ferrández, J.V. 1997. Atlas de la flora del Pirineo aragonés. Vol. I. Instituto de Estudios Altoaragoneses-Consejo de Protección de la Naturaleza de Aragón.

Villar, L.; Sesé, J.A.; Ferrández, J.V. 2001. Atlas de la flora del Pirineo aragonés. Vol. II. 
Instituto de Estudios Altoaragoneses-Consejo de Protección de la Naturaleza de Aragón.

Vivant, J. 1971. Sur trois phanérogames adventices dans le midi de la France. Monde des Plantes 369: 8.

Vives, J. 1964. Vegetación de la alta cuenca del Cardener. Estudio florístico y fitocenológico comarcal. Acta Geobotanica Barcinonensia. Vol. 1.

Wieseler, S. 2005. Fact Sheet: Siberian Elm. http://www.nps.gov/plants/alien/ (Consulta: 19-VII-2013). 
